\title{
Macro-Micro Element Variation in Traditionally Grown Einkorn (Triticum monococcum L. subsp. monococcum) and Emmer Wheat (Triticum dicoccon Schrank)
}

\author{
Nusret Zencirci 1, ${ }^{*}$, Fatma Pehlivan Karakas ${ }^{(1}$, Bulent Ordu(i)2
}

${ }^{1}$ Bolu Abant Izzet Baysal University, Art and Science Faculty, Biology Department, 14200, Gölköy, Bolu, Turkey ${ }^{2}$ Bolu Abant Izzet Baysal University, Faculty of Economics and Administrative Sciences, 14200, Gölköy, Bolu, Turkey

\begin{abstract}
Einkorn (Triticum monococcum L. subsp. monococcum) and emmer wheat (T. dicoccon (Schrank) Schubl.), disease and insect resistant, macro and microelement rich, and high quality are still grown in Turkey highlands (1000$1400 \mathrm{~m}$ ). In this study, plant and soil samples were sampled for macro and micro elements and quality where appropriate. Nine traditional einkorn and emmer wheat farms soils were sampled in Bolu, Kastamonu, Karabük, Sinop, and Samsun provinces in the Western Black Sea Region, Turkey. Plants were sampled during July-August 2016. Methods applied according to the literature. Except for crude ash and copper in grains and the total salt and EC in soils, characters significantly differed. Grain wise, Population-4 had the highest $\mathrm{P}, \mathrm{K}, \mathrm{Cu}, \mathrm{Fe}$, and $\mathrm{Mn}$; Kunduru-1149 had the highest 1000-grain weight, crude protein, energy, raw cellulose, and hectolitre; Population- 8 had the highest energy, crude oil, carbohydrate, and starch. Soil wise, Population-5 had the highest $\mathrm{Cu}, \mathrm{Ca}$, and $\mathrm{Mg}$; Population- 8 had the highest N, Fe, and Mn; Population- 2 had the highest $\mathrm{N}$ and $\mathrm{Zn}, \mathrm{CaCO}_{3}$, active lime, $\mathrm{EC}, \mathrm{K}_{2} \mathrm{O}$, organic matter, $\mathrm{P}_{2} \mathrm{O}_{5}$, and salt. Correlations among grains were highly significant for $\mathrm{N}-\mathrm{Cu}, \mathrm{P}-\mathrm{Mn}, \mathrm{P}-\mathrm{K}$, carbohydrate-starch, energy-starch, and energy-carbohydrate. Correlations among soil samples were highly significant between $\mathrm{Fe}-\mathrm{Mn}$, total $\mathrm{N}-\mathrm{Mn}, \mathrm{CaCO}_{3}$-active lime, saturationsalt, organic matter- $\mathrm{P}_{2} \mathrm{O}, \mathrm{CaCO}_{3}-\mathrm{K}_{2} \mathrm{O}$, and active lime- $\mathrm{K}_{2} \mathrm{O}$. In conclusion, there was a wide variation in traditionally grown einkorn and emmer grain and soils in the Western Black Sea Region.
\end{abstract}

\section{ARTICLE HISTORY}

Received: Aug. 21, 2020

Revised: June 08, 2021

Accepted: July 26, 2021

\section{KEYWORDS}

Crop Nutrition,

Hulled Wheat, In Situ Conservation, Western Black Sea.

\section{INTRODUCTION}

Wheat, a major food grain, is increasingly required especially in developing countries because of the food need of fast-growing human population. It is the type of grain with the highest protein content among the cereals and provides more than $20 \%$ of the daily calorie needed by people living on Earth (Peng et al., 2011a; Peng et al., 2011b). It is also rich in micronutrients (Cummins \& Roberts-Thomson, 2009). Among wheat species, einkorn (Triticum monococcum subsp. monococcum) and emmer (T. dicoccon (Schrank) Schubl.) are two primary wheat

*CONTACT: Nusret Zencirci $\bigotimes$ nzencirci@yahoo.com Bolu Abant IzzetBaysal University, Art and Science Faculty, Biology Department, 14200, Gölköy, Bolu, Turkey 
species, of which einkorn is the first cultivated one (Karagöz, 1996; Nesbitt, 1995; Giuliani et al., 2009).

Previous studies revealed that the gene centre of these wheat species is South East Anatolia (Diyarbakır-Karacadağ region), Turkey (Heun et al., 1997; Dubcovsky \& Dvorak, 2007; Shewry, 2009; Özkan et al., 2010) and they still have been naturally grown in the area called Fertile Crescent (Zohary \& Hopf, 2000; Özkan et al., 2010). The first domesticated plants in the Fertile Crescent were einkorn, emmer, barley, peas, lentils, chickpeas, sourdough, and flax (Zohary \& Hopf, 2000). Einkorn is diploid $(2 \mathrm{n}=2 \mathrm{x}=14$, AA genome), and emmer is tetraploid $(2 \mathrm{n}=4 \mathrm{x}=28$, AABB genome) (Szabo \& Hammer, 1996).

In Turkey, einkorn (Iza/Siyez) and emmer (kaplıca / çatalsiyez / gernik / kavılca) are still grown in limited areas of poor mountainous areas of the Western Black Sea Region, which starts from the western edge of Kizılirmak delta, extends to the east of Adapazarı and Bilecik, and reaches $2000 \mathrm{~m}$ above sea level on the West (Kan et al., 2015). Sloppy mountains make mechanized agriculture difficult and animal and manpower in the region is a must. Region has variously dark, humus-rich acidic washed soils. Every season is rainy. The annual temperature difference is low. These primary-primitive species are widely used as animal feed and organic / good bulgur production due to its favoured flavour. While einkorn is used for bulgur production and, to some extent, as animal feed around Kastamonu and Bolu provinces, emmer is generally for animal feeding in Sinop, Samsun, and Karabük. It is known that the local people used to make bread from emmer as well.

Einkorn and emmer are resistant to frost, drought, and diseases. Their hulled structure protects them especially in the storage and in the field (Nesbitt \& Samuel, 1996). They are rich in raw fibre, antioxidants, minerals, and protein, with low glycaemic index and cholesterol. They are reported to have some protective effects against diabetes, cancer, and cardiovascular diseases. Einkorn and emmer contain more zinc, iron, and copper (Suchowilska et al., 2012) and selenium than bread wheat (Lachman et al., 2011). They are also rich in starch, fibre, minerals, and phytochemicals (Pekcan \& Köksal, 2006; Arzani et al., 2017).

In this study, we collected five einkorn and four emmer populations from Bolu, Kastamonu, Karabük, Samsun, and Sinop provinces in July-August 2016. The registered check cultivars for grain comparison included were Bezostaja-1 bread (Triticum aestivum L.) and Kunduru-1149 durum (Triticum durum Desf.). Both wheat grain and soil samples had been analysed. In the soil samples we collected, macro nitrogen $(\mathrm{N})$, magnesium $(\mathrm{Mg})$, calcium $(\mathrm{Ca})$, potassium $(\mathrm{K})$, micro iron $(\mathrm{Fe})$, manganese $(\mathrm{Mn})$, zinc $(\mathrm{Zn})$, sodium $(\mathrm{Na})$, and copper $(\mathrm{Cu})$ elements and water saturation, total salt, saturation with water $\mathrm{pH}, \mathrm{CaCO}_{3}$ (calcium carbonate), active lime, $\mathrm{K}_{2} \mathrm{O}$ (potassium oxide), $\mathrm{P}_{2} \mathrm{O}_{5}$ (phosphorus pentoxide), electrical conductivity (EC), and organic matter were determined. In wheat grain samples $\mathrm{N}, \mathrm{P}, \mathrm{K}, \mathrm{Fe}, \mathrm{Zn}, \mathrm{Mn}, \mathrm{Cu}, 1000$ grain weight, crude protein, energy, crude cellulose, crude oil, hectolitre, carbohydrate, starch, sugar, and raw ash were analysed.

\section{MATERIAL and METHODS}

The study material was five einkorn and four emmer wheats from five provinces of the Western Black Sea Region (Bolu, Kastamonu, Karabük, Samsun, and Sinop), which were collected in July-August 2016. Bezostaja-1 bread and Kunduru-1149 durum wheat were the controls. We recorded altitude, latitude, longitude, soil structure, and geographical characteristics (Table 1) of the collection sites. Environment expectedly affects yield, quality, and nutrition of einkorn (Pomeranz, 1971).

In grain samples, some macro $(\mathrm{N}, \mathrm{P}$, and $\mathrm{K}$ ) and micro (Fe, $\mathrm{Mn}, \mathrm{Zn}$, and $\mathrm{Cu}$ ) elements, energy, carbohydrate, protein, crude protein, starch, fat, fibre, sugar, crude ash, 1000 grain weight, \% protein, hectolitre analyses were carried out in Konya Laboratory and Storage 
Company. Total nitrogen, saturation, salt, EC, $\mathrm{pH}$, lime, active lime, phosphorus, potassium, calcium, magnesium, iron, manganese, zinc, copper, sodium, and organic matter in the soil samples were determined in Bolu Soil and Leaf Analysis Laboratory (Anonymous, 1993; 1998; 2013; 2016).

Table 1. Populations, their species, origins, altitudes (m), latitudes, longitudes, soil structure, and some soil characteristics (Bezostaja-1 and Kunduru-1149 were controls).

\begin{tabular}{|c|c|c|c|c|c|c|c|c|}
\hline 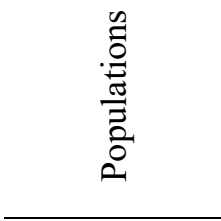 & 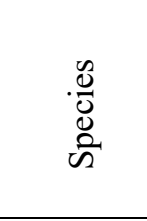 & . & 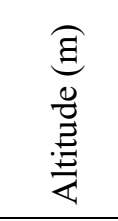 & : & 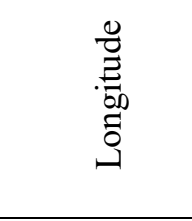 & 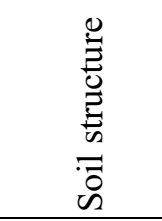 & 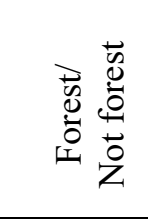 & 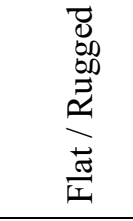 \\
\hline Population-1 & Emmer & $\begin{array}{l}\text { Karabük, } \\
\text { Safranbolu }\end{array}$ & 811 & $41^{\circ} 25^{\prime} 15^{\prime \prime}$ & $32^{\circ} 48^{\prime \prime}$ & Standard & $\begin{array}{l}\text { Half } \\
\text { forest }\end{array}$ & Rugged \\
\hline Population-2 & Einkorn & $\begin{array}{l}\text { Kastamonu, } \\
\text { (İhsangazi, } \\
\text { Akkaya } \\
\text { Village) } \\
\end{array}$ & 787 & $41^{\circ} 13^{\prime} 0^{\prime \prime}$ & $33^{\circ} 28^{\prime} 58^{\prime \prime}$ & Clay soil & $\begin{array}{l}\text { Not } \\
\text { forest }\end{array}$ & Flat \\
\hline Population-3 & Einkorn & $\begin{array}{l}\text { Kastamonu, } \\
\text { İhsangazi, } \\
\text { Çatalyazı } \\
\text { Village }\end{array}$ & 1258 & $41^{\circ} 9^{\prime} 37^{\prime \prime}$ & $33^{\circ} 37^{\prime} 17^{\prime \prime}$ & Standard & $\begin{array}{l}\text { Half } \\
\text { forest }\end{array}$ & Rugged \\
\hline Population-4 & Einkorn & $\begin{array}{l}\text { Kastamonu, } \\
\text { İhsangazi, } \\
\text { Enbiya } \\
\text { Village } \\
\end{array}$ & 820 & $41^{\circ} 12^{\prime} 52^{\prime \prime}$ & $33^{\circ} 30^{\prime} 52^{\prime \prime}$ & Standard & $\begin{array}{l}\text { Half } \\
\text { forest }\end{array}$ & Flat \\
\hline Population-5 & Emmer & $\begin{array}{l}\text { Samsun, } \\
\text { Lâdik, } \\
\text { Çamlıköy }\end{array}$ & 1055 & $40^{\circ} 52^{\prime} 39^{\prime \prime}$ & $35^{\circ} 45^{\prime} 27^{\prime \prime}$ & Hard soil & $\begin{array}{l}\text { Some } \\
\text { forest }\end{array}$ & Rugged \\
\hline Population-6 & Emmer & $\begin{array}{l}\text { Sinop, } \\
\text { Durağan, } \\
\text { Kirencik } \\
\text { Village }\end{array}$ & 1295 & $41^{\circ} 25^{\prime} 37^{\prime \prime}$ & $35^{\circ} 21^{\prime} 23^{\prime \prime}$ & $\begin{array}{l}\text { Hard, } \\
\text { stony } \\
\text { soil }\end{array}$ & $\begin{array}{l}\text { Some } \\
\text { forest }\end{array}$ & Rugged \\
\hline Population-7 & Einkorn & Bolu, Seben & 911 & $40^{\circ} 21^{\prime} 38^{\prime \prime}$ & $31^{\circ} 30^{\prime} 50^{\prime \prime}$ & Clay soil & $\begin{array}{l}\text { Some } \\
\text { forest }\end{array}$ & Flat \\
\hline Population- 8 & Emmer & $\begin{array}{l}\text { Sinop, } \\
\text { Durağan, } \\
\text { Gölgerişi } \\
\text { Village }\end{array}$ & 1116 & $41^{\circ} 26^{\prime} 14^{\prime \prime}$ & $35^{\circ} 23^{\prime} 1^{\prime \prime}$ & Standard & $\begin{array}{l}\text { Some } \\
\text { forest }\end{array}$ & Rugged \\
\hline Population-9 & Einkorn & $\begin{array}{l}\text { Bolu, Seben, } \\
\text { Musosoflar } \\
\text { Village }\end{array}$ & 920 & $40^{\circ} 21^{\prime} 38^{\prime \prime}$ & $31^{\circ} 30^{\prime} 47^{\prime \prime}$ & Clay soil & $\begin{array}{l}\text { Some } \\
\text { forest }\end{array}$ & Rugged \\
\hline Bezostaja-1 & $\begin{array}{l}\text { Bread } \\
\text { wheat }\end{array}$ & & & & & & & \\
\hline
\end{tabular}

Nitrogen and crude protein in grain samples were analysed by ISO 1871 method (Rossi et al., 2004), crude oil and crude cellulose by AACC 32-25 method (Anonymous, 2010), crude ash by AACC 08-01 basic method (Anonymous, 2010), Hectolitre by TS EN ISO 7971-3 method (Anonymous, 2009), 1000 grain weight by TS 2974 method (Anonymous, 2016), starch (\%) by TKB method (Anonymous, 2013), sugar (\%) by NMKL 148 method (Anonymous, 1993), carbohydrate and energy by calculation method (Emmanuel et al., 2014), and $\mathrm{Cu}, \mathrm{Fe}$, Mn, Zn, K, and P by NMKL 161 (Anonymous, 1998). Total nitrogen in soil (total N\%) was 
determined by Kjeldahl method (Horwitz, 1955; Jackson, 1958; Chapman \& Pratt, 1961; Black, 1965; Hanway 1968; Ülgen \& Ateşalp, 1972), water saturation by pure water saturation method (Richards, 1954; Bower \& Wilcox,1965; Özbek \& Aydeniz, 1967), saturation with water Ph by Potentiometric measuring method using $\mathrm{pH}$-meter, total salt $\%$ by the method of determining the salinity of the soil by measuring its resistance to electrical power (Hindistan \& İnceoğlu, 1962; Peech, 1965; Mclean, 1973;), CaCo3 (lime) \% by Scheibler calcimetry method (Çağlar, 1949), active lime\% by Drouineau-Galet Method (Drouineau, 1942), $\mathrm{K}_{2} \mathrm{O}$ (Potassium oxide) by measuring fleym fotometre (Chapman \& Pratt, 1961); Jackson, 1958; Doll \& Lucas, 1973; Pratt, 1965), $\mathrm{P}_{2} \mathrm{O}_{5}$ (Phosphorus pentoxide) by Olsen method (Olsen et al., 1954), electrical conductivity $(\mathrm{EC}) \mathrm{ms} / \mathrm{cm}$ by measuring electrical conductivity in saturation extract method (Richards, 1954; Öztan \& Ülgen, 1961; Öztan \& Munsuz, 1961; Ayy1ldı et al., 1983;), Na, K, $\mathrm{Ca}$, and Mg by $1 \mathrm{~N}$ NH4OAc method (Carson, 1980), Zn, Fe, Mn, and Cu by DTPA $0.005 \mathrm{M}$ extraction method (Berger \& Troug, 1939; Viets, 1962; Follet \& Linsay, 1970), organic matter by Modified the Walkley-Black Method (Allison, 1965; Walkley, 1946). Analysis of variance (ANOVA) and Least Significant Difference (LSD) for grain and soil characteristics, correlations among all character pairs of grain quality, soil macro-micro elements, and other soil characteristics, and dendrogram for all grain and all soil characteristics were run by SPSS version 25 .

\section{RESULTS / FINDINGS}

The nutrition and macro-micro elements of wheat grains and soils collected in Bolu, Kastamonu, Samsun, Sinop, and Karabük provinces in the Western Black Sea Region were presented as follows:

\subsection{Macro-Micro Element Diversity in Wheat Grains}

Three replication randomized block design was applied for macro (N, P, and $\mathrm{K}$ ) and microelements $(\mathrm{Cu}, \mathrm{Fe}, \mathrm{Zn}$, and $\mathrm{Mn}$ ) in wheat grains (Table 2).

Table 2. Macro-micro element means squares of wheat grains.

\begin{tabular}{lcccccccc}
\hline $\begin{array}{l}\text { Source of } \\
\text { Variation }\end{array}$ & $D F$ & $\begin{array}{c}\mathrm{N} \\
(\mathrm{mg} / \mathrm{kg})\end{array}$ & $\begin{array}{c}\mathrm{P} \\
(\mathrm{kg} / \mathrm{kg})\end{array}$ & $\begin{array}{c}\mathrm{K} \\
(\mathrm{mg} / \mathrm{kg})\end{array}$ & $\begin{array}{c}\mathrm{Cu} \\
(\mathrm{mg} / \mathrm{kg})\end{array}$ & $\begin{array}{c}\mathrm{Fe} \\
(\mathrm{mg} / \mathrm{kg})\end{array}$ & $\begin{array}{c}\mathrm{Zn} \\
(\mathrm{mg} / \mathrm{kg})\end{array}$ & $\begin{array}{c}\mathrm{Mn} \\
(\mathrm{mg} / \mathrm{kg})\end{array}$ \\
\hline Entries & 10 & $0.46^{*}$ & $1216.26^{*}$ & $747.75^{*}$ & 1.10 & $296.68^{*}$ & $369.49^{*}$ & $218.26^{*}$ \\
Error & 22 & 0.02 & 0.055 & 0.625 & 106711.38 & 0.64 & 4.01 & 1.08 \\
\hline
\end{tabular}

$D F$ : Degrees of freedom; * significant at 0.05 .

Macro and microelement mean squares statistically differentiated in grains (Table 2). The differences were significant for $\mathrm{N}, \mathrm{P}, \mathrm{K}, \mathrm{Fe}, \mathrm{Zn}$, and $\mathrm{Mn}(p<0.05)$, but insignificant for $\mathrm{Cu}$ (Table 3). The error which is lower for $\mathrm{P}, \mathrm{K}, \mathrm{Fe}, \mathrm{Zn}$, and $\mathrm{Mn}$ increased the significance of $\mathrm{F}$ test.

Kunduru-1149 had the highest N (3.02 mg/kg). Emmer grain from Sinop Durağan (Population-6), while it had the lowest N (1.68 mg/kg). Einkorn grain from Kastamonu İhsangazi (Population-4) had the highest P $(5687.00 \mathrm{mg} / \mathrm{kg})$, while Bolu Seben (Population-7) einkorn grain had the lowest $(3.472 .67 \mathrm{mg} / \mathrm{kg})$. The einkorn from Kastamonu İhsangazi (Population-4) had the highest K $(565.00 \mathrm{mg} / \mathrm{kg})$, while Bezostaja-1 had the lowest $(3.842 .00$ $\mathrm{mg} / \mathrm{kg})$.

Kunduru-1149 had the highest $\mathrm{Cu}(6.42 \mathrm{mg} / \mathrm{kg})$, while emmer grain from Sinop Durağan (Population-6) had the lowest $(4.16 \mathrm{mg} / \mathrm{kg})$. Einkorn from Kastamonu İhsangazi (Population4) had the highest Fe $(59.32 \mathrm{mg} / \mathrm{kg})$; on the other hand, emmer from Sinop Durağan 
(Population-8) had the lowest $(27.30 \mathrm{mg} / \mathrm{kg})$. Kastamonu İhsangazi (Population-2) einkorn wheat had the highest Zn (74.68), while Bezostaja-1 had the lowest (35.62 mg/kg). Einkorn from Kastamonu İhsangazi (Population-4) had the highest $\mathrm{Mn}(53.75 \mathrm{mg} / \mathrm{kg})$, while emmer from Sinop Durağan Population-6 had the lowest $(24.48 \mathrm{mg} / \mathrm{kg})$. When we look into the relevant literature, in a study (Allison, 1965) the concentrations of five macro and fifteen microelements in the whole grain of spring lines of emmer, einkorn, spelt and two common wheat cultivars, all grown under identical environmental conditions, were determined by ICPSFMS analysis. Triticum species studied differed significantly for $\mathrm{P}, \mathrm{Zn}, \mathrm{Fe}, \mathrm{Mn}$, and $\mathrm{Cu}$ concentrations as in our study. The grain of all hulled wheats, compared with common wheat, contained significantly more $\mathrm{Zn}$ (from $34 \%$ to $54 \%$ ), which was lower than einkorn of ours; $\mathrm{Fe}$ (from $31 \%$ to $33 \%$ ) was lower than our emmer samples. In most cases, there were no relationships between the concentrations of the analysed elements, except for significant positive correlations between the levels of $\mathrm{Fe}, \mathrm{Zn}$, and $\mathrm{Mn}$, in einkorn and emmer. The classical linear discriminant analysis enabled us to distinguish between the three Triticum species studied for the concentrations of all analysed elements in their grain. A significant discrimination indicates that the concentrations of the investigated elements are a species-specific character. A strong correlation between $\mathrm{Zn}, \mathrm{Fe}$, and $\mathrm{Mn}$ could have important implications for wheat quality breeding. Analysed 150 bread wheat lines of diverse origin and 25 lines of durum, spelt, einkorn, and emmer wheat micronutrient concentration varied in grain. Substantial variation existed among the grain $\mathrm{Fe}$ and $\mathrm{Zn}$ of 75 lines as in some of our samples.

Table 3. Entry ranking for wheat macro-micro elements by LSD.

\begin{tabular}{|c|c|c|c|c|c|c|c|}
\hline Entries & $\begin{array}{c}\mathrm{N} \\
(\mathrm{mg} / \mathrm{kg})\end{array}$ & $\begin{array}{c}\mathrm{P} \\
(\mathrm{mg} / \mathrm{kg})\end{array}$ & $\begin{array}{c}\mathrm{K} \\
(\mathrm{mg} / \mathrm{kg})\end{array}$ & $\begin{array}{c}\mathrm{Cu} \\
(\mathrm{mg} / \mathrm{kg})\end{array}$ & $\begin{array}{c}\mathrm{Fe} \\
(\mathrm{mg} / \mathrm{kg})\end{array}$ & $\begin{array}{c}\mathrm{Zn} \\
(\mathrm{mg} / \mathrm{kg})\end{array}$ & $\begin{array}{c}\mathrm{Mn} \\
(\mathrm{mg} / \mathrm{kg})\end{array}$ \\
\hline $\begin{array}{l}\text { Population-1 } \\
\text { Karabük- } \\
\text { Safranbolu }\end{array}$ & $2.11^{\mathrm{c}^{*}}$ & $4324.33^{\mathrm{e}}$ & $4721.67^{\mathrm{c}}$ & $4.64^{\mathrm{a}}$ & $35.81^{\mathrm{e}}$ & $48.13^{\mathrm{e}}$ & $34.16^{c}$ \\
\hline $\begin{array}{l}\text { Population-2 } \\
\text { Kastamonu- } \\
\text { İhsangazi }\end{array}$ & $2.20^{\mathrm{b}}$ & $4217.33^{f}$ & $4240.67^{f}$ & $4.79^{\mathrm{a}}$ & $30.67^{f}$ & $74.68^{\mathrm{a}}$ & $44.75^{\mathrm{b}}$ \\
\hline $\begin{array}{l}\text { Population-3 } \\
\text { Kastamonu- } \\
\text { İhsangazi }\end{array}$ & $1.93^{\mathrm{c}}$ & $4341.33^{\mathrm{d}}$ & $4774.67^{c}$ & $4.74^{\mathrm{a}}$ & $29.30^{\mathrm{f}}$ & $55.05^{\mathrm{c}}$ & $36.38^{c}$ \\
\hline $\begin{array}{l}\text { Population-4 } \\
\text { Kastamonu- } \\
\text { İhsangazi }\end{array}$ & $2.13^{\mathrm{c}}$ & $5687.00^{\mathrm{a}}$ & $5651.00^{\mathrm{a}}$ & $4.86^{\mathrm{a}}$ & $59.32^{\mathrm{a}}$ & $62.05^{\mathrm{b}}$ & $53.75^{\mathrm{a}}$ \\
\hline $\begin{array}{l}\text { Population-5 } \\
\text { Samsun-Ladik }\end{array}$ & $1.97^{\mathrm{c}}$ & $3774.33^{\mathrm{i}}$ & $4344.00^{\mathrm{e}}$ & $4.67^{\mathrm{a}}$ & $30.34^{f}$ & $42.65^{\mathrm{g}}$ & $29.64^{\mathrm{e}}$ \\
\hline $\begin{array}{l}\text { Population-6 } \\
\text { Sinop-Durağan }\end{array}$ & $1.68^{\mathrm{d}}$ & $3926.33^{\mathrm{h}}$ & $4452.33^{\mathrm{d}}$ & $4.16^{\mathrm{a}}$ & $27.55^{\mathrm{g}}$ & $38.15^{\mathrm{h}}$ & $24.48^{\mathrm{f}}$ \\
\hline $\begin{array}{l}\text { Population-7 } \\
\text { Bolu-Seben } \\
\end{array}$ & $2.50^{\mathrm{b}}$ & $3472.67^{j}$ & $4176.00^{\mathrm{g}}$ & $5.37^{\mathrm{a}}$ & $46.30^{\mathrm{b}}$ & $53.75^{\mathrm{c}}$ & $31.07^{\mathrm{d}}$ \\
\hline $\begin{array}{l}\text { Population-8 } \\
\text { Sinop-Durağan }\end{array}$ & $1.55^{\mathrm{d}}$ & $4420.33^{c}$ & $5123.67^{\mathrm{b}}$ & $4.52^{\mathrm{a}}$ & $27.30^{\mathrm{g}}$ & $45.72^{\mathrm{f}}$ & $32.41^{\mathrm{d}}$ \\
\hline $\begin{array}{l}\text { Population-9 } \\
\text { Bolu-Seben }\end{array}$ & $2.19^{\mathrm{b}}$ & $3328.33^{\mathrm{k}}$ & $4267.67^{f}$ & $5.33^{\mathrm{a}}$ & $42.87^{\mathrm{c}}$ & $51.44^{\mathrm{d}}$ & $28.07^{\mathrm{e}}$ \\
\hline Bezostaja-1 & $2.02^{\mathrm{c}}$ & $4081.33^{\mathrm{g}}$ & $3842.00^{\mathrm{h}}$ & $4.59^{\mathrm{a}}$ & $30.11^{\mathrm{f}}$ & $35.62^{\mathrm{i}}$ & $34.41^{\mathrm{c}}$ \\
\hline Kunduru-1149 & $3.02^{\mathrm{a}}$ & $4647.00^{\mathrm{b}}$ & $4496.00^{d}$ & $6.42^{\mathrm{a}}$ & $38.22^{\mathrm{d}}$ & $46.31^{\mathrm{e}}$ & $43.57^{b}$ \\
\hline LSD 0.05 & 0.32 & 16.68 & 56.24 & 734.82 & 1.81 & 4.50 & 2.35 \\
\hline
\end{tabular}

\footnotetext{
* The same letter in the same column describes no difference otherwise there is a difference.
} 


\subsection{Quality Characteristics of Grain Samples}

Thousand kernel weight (1000 KW), crude protein $\%$, energy, raw ash $\%$, crude cellulose $\%$, raw oil \%; hectolitre $(\mathrm{kg} / \mathrm{hl})$, starch \%, and total sugar \% in grain samples collected from Bolu, Kastamonu, Samsun, Sinop, and Karabük in the Western Black Sea Region are presented as follows:

ANOVA designated significance $(p<0.05)$ for thousand kernel weight $(T K W)$, crude protein, energy, crude cellulose, raw oil, hectolitre, carbohydrate, starch, and total sugar, while raw ash was designated as insignificant (Table 4). Higher MS error for raw ash was the most likely reason for insignificance. Kunduru-1149 had the heaviest TKW $(50.55 \mathrm{~g})$, while Kastamonu İhsangazi (Population-2) einkorn had the lightest (21.55g). Kunduru-1149 had the highest protein (16.50\%); on the other hand, Sinop Durağan (Population-8) emmer grain had the lowest (8.75 \%). Sinop Durağan emmer (Population-8) had the highest energy (319.00 kcal/100 gr), while Kastamonu İhsangazi (Population-2) einkorn had the lowest (279.67). Bolu Seben (Population-9) had the highest raw ash (2.34 g), while Bolu Seben (Population-7) einkorn wheat had the lowest (1.42). Kunduru-1149 had the highest crude cellulose (3.80\%), while Kastamonu İhsangazi (Population-4) einkorn wheat had the lowest (1.28 \%). Sinop Durağan emmer (Population-8) had the highest raw oil (2.04\%), while Bezostaja-1 had the lowest (0.42 \%). Bolu Seben (Population-9) einkorn wheat had the heaviest hectolitre (80.33 kg/hl), while Karabuk Safranbolu (Population-1) had the lightest (71.97 kg/hl). Sinop Durağan (Population8) emmer wheat had the highest carbohydrate $(64.63 \%)$, while Kastamonu İhsangazi (Population-2) einkorn had the lowest (54.50 kg/hl). Sinop Durağan (Population-8) emmer had the highest starch (63.28 \%), while Kastamonu İhsangazi (Population-2) einkorn wheat sample had the lowest (53.63\%). Kastamonu İhsangazi (Population-4) einkorn had the highest total sugar (1.69\%), while Bezostaja-1 had the lowest (0.42\%) (Table 5). Old varieties and landraces of wheat may play an important role for food security since they both provide genes readily available to breeders and they perform sustainably higher yield in marginal lands. Today in many countries including Italy, Turkey, Germany, and the USA cereal sector requires seed companies that breed specifically adapted cultivars for organic and biodynamic farms and study macro and microelements in these varieties. In such a context, the dendrogram (Figure 1), based on the averages of macro-micro $\mathrm{N}(\mathrm{mg} / \mathrm{kg}), \mathrm{P}(\mathrm{mg} / \mathrm{kg}), \mathrm{K}(\mathrm{mg} / \mathrm{kg}), \mathrm{Fe}(\mathrm{mg} / \mathrm{kg}), \mathrm{Cu}(\mathrm{mg} / \mathrm{kg}), \mathrm{Zn}$ $(\mathrm{mg} / \mathrm{kg})$, and $\mathrm{Mn}(\mathrm{mg} / \mathrm{kg})$ elements as well as $1000 \mathrm{KW}(\mathrm{g})$, crude protein (\%), energy ( $\mathrm{kcal} / 100$ gr), raw ash $\%$, crude cellulose $\%$, raw oil $\%$, hectolitre $\%$, carbohydrate $\%$, starch $\%$, and total sugar $\%$, separated eleven wheat grain samples into two main groups.

Thirty-three wheat (Triticum aestivum L.) samples were assessed for their physical and chemical analysis, protein quality and quantity, and metabolizable energy and contrary to our findings none of the values, or combination of values, from the physical and chemical analyses showed significant correlation with metabolizable energy values.

Table 4. Grain quality mean squares.

\begin{tabular}{|c|c|c|c|c|c|c|c|c|c|c|c|}
\hline 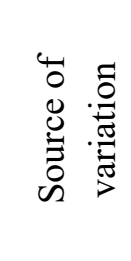 & 这 & 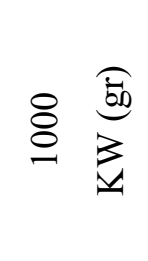 & 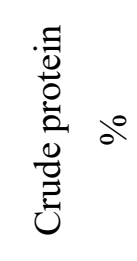 & 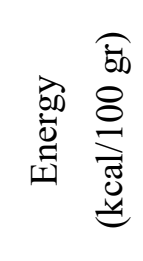 & 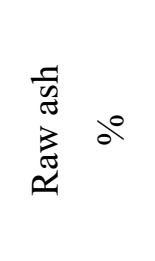 & 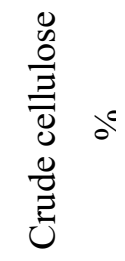 & 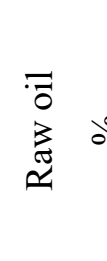 & 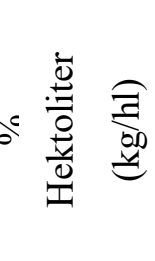 & 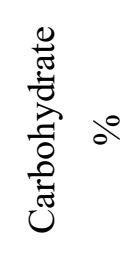 & 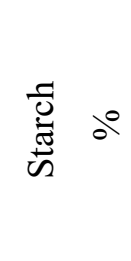 & 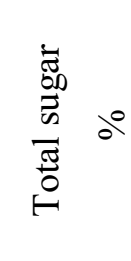 \\
\hline Entries & 10 & $273.98 *$ & $13.07 *$ & $346.09 *$ & $140.00^{\mathrm{ns}}$ & $1.47^{*}$ & $0.55 *$ & $29.53 *$ & $30.39 *$ & $25.92 *$ & $0.33 *$ \\
\hline Error & 22 & 1.03 & 0.47 & 50.33 & 1563.82 & 0.01 & 0.01 & 4.58 & 2.23 & 2.54 & 0.0043 \\
\hline
\end{tabular}

DF: Degrees of freedom; ${ }^{*}$ Significant at 0.05 
Table 5. Entry ranking for wheat grain quality diversity by LSD.

\begin{tabular}{|c|c|c|c|c|c|c|c|c|c|c|}
\hline Entries & $\frac{3}{8} \overparen{E}$ & $\begin{array}{l}. \Xi \\
0 \\
0 \\
0 \\
0 \\
0 \\
0 \\
0 \\
0\end{array}$ & 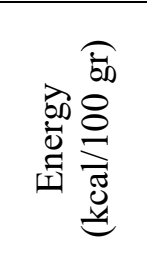 & 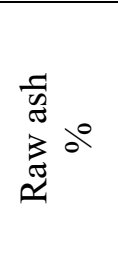 & 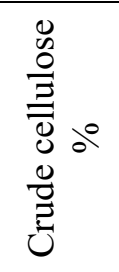 & 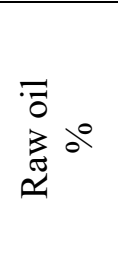 & 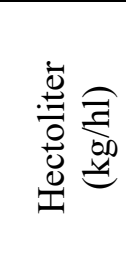 & 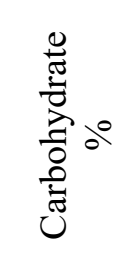 & 晜 $0^{\circ}$ & 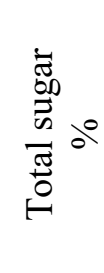 \\
\hline $\begin{array}{l}\text { Popu } \\
\text { Karal } \\
\text { Safra }\end{array}$ & $87^{\mathrm{f*}^{*}}$ & $12.07^{b}$ & $07.00^{\mathrm{a}}$ & $1.77^{\mathrm{d}}$ & $3.04^{\mathrm{b}}$ & $1.62^{b}$ & $71.97^{b}$ & $61.24^{\mathrm{b}}$ & $60.32^{\mathrm{a}}$ & $0.58^{\mathrm{d}}$ \\
\hline $\begin{array}{l}\text { Popul } \\
\text { Kasta } \\
\text { İhsan }\end{array}$ & $.55^{\mathrm{h}}$ & $12.47^{\mathrm{b}}$ & $279.67^{b}$ & $1.72^{\mathrm{f}}$ & $2.99^{\mathrm{b}}$ & $1.25^{\mathrm{c}}$ & $77.42^{\mathrm{a}}$ & $54.50^{\mathrm{c}}$ & $53.63^{c}$ & $0.83^{b}$ \\
\hline Kas & $.57^{\mathrm{d}}$ & $11.13^{\mathrm{c}}$ & b & $1.70^{\mathrm{f}}$ & $2.44^{\mathrm{c}}$ & $1.43^{\mathrm{b}}$ & $80.07^{\mathrm{a}}$ & $56.41^{\mathrm{c}}$ & $55.46^{\mathrm{c}}$ & $.91^{\mathrm{b}}$ \\
\hline $\begin{array}{l}\text { Popu } \\
\text { Kast } \\
\text { İhsan } \\
\end{array}$ & $30^{\mathrm{g}}$ & $12.25^{\mathrm{b}}$ & $305.67^{\mathrm{a}}$ & $2.01^{\mathrm{b}}$ & $1.28^{\mathrm{f}}$ & $1.45^{\mathrm{b}}$ & $78.02^{\mathrm{a}}$ & $60.54^{\mathrm{b}}$ & $59.13^{b}$ & $1.69^{\mathrm{a}}$ \\
\hline Sams & $29.18^{\mathrm{f}}$ & $11.25^{\mathrm{b}}$ & $302.57^{\mathrm{a}}$ & $1.64^{\mathrm{f}}$ & $2.27^{\mathrm{c}}$ & $1.71^{\mathrm{b}}$ & $70.67^{b}$ & $60.45^{\mathrm{b}}$ & $59.95^{\mathrm{a}}$ & $0.66^{\mathrm{c}}$ \\
\hline $\begin{array}{l}\text { Population-6 } \\
\text { Sinop-Durağan }\end{array}$ & $32.13^{\mathrm{e}}$ & $9.68^{c}$ & $300.67^{a}$ & $1.73^{\mathrm{e}}$ & $2.10^{\mathrm{d}}$ & $1.94^{\mathrm{a}}$ & $75.37^{b}$ & $60.93^{b}$ & $60.12^{\mathrm{a}}$ & $0.82^{\mathrm{b}}$ \\
\hline $\begin{array}{l}\text { Population-7 } \\
\text { Bolu-Seben }\end{array}$ & $27.20^{\mathrm{f}}$ & $14.27^{\mathrm{b}}$ & $296.33^{\mathrm{a}}$ & $1.42^{\mathrm{h}}$ & $2.40^{\mathrm{c}}$ & $1.27^{\mathrm{c}}$ & $79.15^{\mathrm{a}}$ & $57.23^{c}$ & $56.24^{\mathrm{b}}$ & $0.96^{\mathrm{b}}$ \\
\hline $\begin{array}{l}\text { Population-8 } \\
\text { Sinop-Durağan }\end{array}$ & $37.87^{\mathrm{c}}$ & $8.75^{\mathrm{d}}$ & $311.00^{\mathrm{a}}$ & $1.51^{\mathrm{g}}$ & $1.70^{\mathrm{e}}$ & $2.04^{\mathrm{a}}$ & $75.10^{\mathrm{b}}$ & $64.63^{\mathrm{a}}$ & $63.28^{\mathrm{a}}$ & $0.77^{\mathrm{c}}$ \\
\hline $\begin{array}{l}\text { Population-9 } \\
\text { Bolu-Seben } \\
\end{array}$ & $25.50^{\mathrm{g}}$ & $12.72^{\mathrm{b}}$ & $285.33^{b}$ & $2.34^{\mathrm{a}}$ & $2.13^{\mathrm{d}}$ & $1.50^{\mathrm{b}}$ & $80.33^{\mathrm{a}}$ & $55.47^{\mathrm{c}}$ & $54.68^{c}$ & $0.65^{\mathrm{c}}$ \\
\hline $\mathrm{Bez}$ & $48.10^{\mathrm{b}}$ & $11.61^{\mathrm{b}}$ & $8.67^{b}$ & $1.56^{\mathrm{g}}$ & $2.97^{\mathrm{b}}$ & $.42^{\mathrm{d}}$ & $75.10^{\mathrm{b}}$ & $59.20^{\mathrm{b}}$ & $59.12^{\mathrm{b}}$ & $0.42^{\mathrm{e}}$ \\
\hline Kunc & $50.55^{\mathrm{a}}$ & $16.50^{\mathrm{a}}$ & $.00^{\mathrm{a}}$ & $1.82^{\mathrm{c}}$ & $3.80^{\mathrm{a}}$ & $1.58^{b}$ & $77.57^{\mathrm{a}}$ & $55.16^{\mathrm{c}}$ & $56.37^{b}$ & $0.54^{\mathrm{d}}$ \\
\hline LSD 0.05 & 2.29 & 1.54 & 15.96 & 88.96 & 0.284 & 0.283 & 4.82 & 3.36 & 3.59 & 0.15 \\
\hline
\end{tabular}

* The same letter in the same column describes no difference otherwise there is a difference.

\subsection{Soil Macro-Micro Elements}

Mean squares in ANOVA were significant for macro-micro elements of $\mathrm{N}, \mathrm{P}_{2} \mathrm{O}_{5}, \mathrm{~K}_{2} \mathrm{O}, \mathrm{K}, \mathrm{Na}$, $\mathrm{Fe}, \mathrm{Cu}, \mathrm{Ca}, \mathrm{Zn}, \mathrm{Mn}$, and $\mathrm{Mg}$ (Table 6). The highest $\mathrm{N}(0.74 \mathrm{mg} / \mathrm{kg})$ was in Kastamonu İhsangazi (Population-2) soil sample, while the lowest was in Bolu Seben (Population-7) $(0.13 \mathrm{mg} / \mathrm{kg}$ ). Kastamonu İhsangazi (Population-2) had the highest $\mathrm{P}_{2} \mathrm{O}_{5}(54.90 \mathrm{mg} / \mathrm{kg})$, while Karabük Safranbolu (Population-1) soil sample had the lowest $(0.03 \mathrm{mg} / \mathrm{kg}$ ) (Table 7). Kastamonu İhsangazi (Population-2) had the highest $\mathrm{K}_{2} \mathrm{O}(258.22 \mathrm{mg} / \mathrm{kg}$ ); Sinop Durağan (Population-6) soil sample had the lowest $65.87(\mathrm{mg} / \mathrm{kg})$. Kastamonu İhsangazi (Population-4) had the highest K (371.27 mg/kg), whereas Sinop Durağan (Population-6) had the lowest $(59.43 \mathrm{mg} / \mathrm{kg}$ ). Karabük Safranbolu (Population-1) had the highest $\mathrm{Na}(7.92 \mathrm{mg} / \mathrm{kg}$ ), while Kastamonu İhsangazi (Population-2), Samsun Ladik (Population-5), Sinop Durağan (Population-6), Bolu 
Seben (Population-7), Sinop Durağan (Population-8), and Bolu Seben (Population-9) had the lowest ( 0.01 to $0.00 \mathrm{mg} / \mathrm{kg})$.

Large Fe differences existed among soil samples. Sinop Durağan (Population-8) had the highest (53.15 mg/kg), while Bolu Seben (Population-9) had the lowest (2.20). For $\mathrm{Cu}$, Samsun Ladik (Population-5) soil sample had the highest value with $13.98 \mathrm{mg} / \mathrm{kg}$ result, while Bolu Seben (Population-7) had the lowest value with $3.35 \mathrm{mg} / \mathrm{kg}$ result of soil sample. Samsun Ladik (Population-5) had the highest Ca (5739.67 mg/kg), while Sinop Durağan (Population-8) had the lowest $(3108.37 \mathrm{mg} / \mathrm{kg}$ ). Kastamonu İhsangazi (Population-2) had the highest Zn (4.32 $\mathrm{mg} / \mathrm{kg}$ ), while Kastamonu İhsangazi (Population-3), Bolu Seben (Population-7), and Bolu Seben (Population-9) had the lowest $(0.01 \mathrm{mg} / \mathrm{kg})$. Sinop Durağan (Population-8) had the highest Mn (95.35 mg/kg); Bolu Seben (Population-7) had the lowest (22.23 mg/kg). Samsun Ladik (Population5) had the highest Mg (395.57 mg/kg), while Sinop Durağan (Population-6) had the lowest $(88.17 \mathrm{mg} / \mathrm{kg})$.

Table 6. Mean squares for soil structure factors of $\mathrm{CaCO}_{3} \%$, active lime $\%, \mathrm{EC}, \mathrm{K}_{2} \mathrm{O}$, organic matter $\%, \mathrm{P}_{2} \mathrm{O}_{5}$, water saturation, and saturation with water $\mathrm{pH}$.

\begin{tabular}{|c|c|c|c|c|c|c|c|c|}
\hline 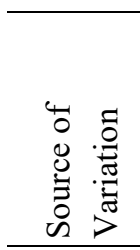 & $\frac{5}{a}$ & 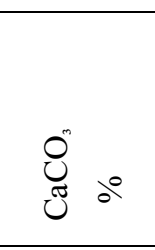 & 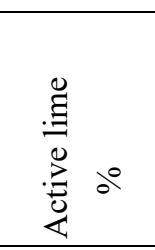 & ن & 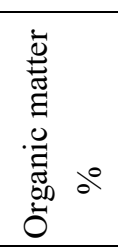 & 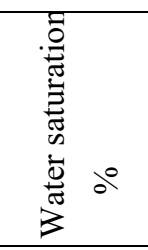 & 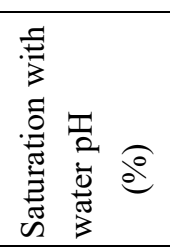 & 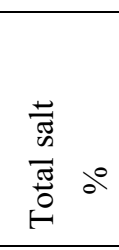 \\
\hline Entries & 10 & $984.16^{*}$ & $246.69^{*}$ & 0.0133 & $2.36^{*}$ & $966.76^{*}$ & $0.72^{*}$ & 0.0001 \\
\hline Enter & 22 & 0.11 & 0.21 & 0.0071 & 0.18 & 10.81 & 0.01 & 0.002 \\
\hline
\end{tabular}

$D F$ : Degrees of freedom; significance at 0.05 .

A comparison of five macro and fifteen microelement concentrations in the whole grain of four emmer, einkorn, spelt, and two common Triticum species showed that Triticum species differed significantly for $\mathrm{P}, \mathrm{Zn}, \mathrm{Fe}, \mathrm{Mn}$, and $\mathrm{Cu}$. The grain of all hulled wheats, compared with common wheat, contained significantly higher Zn (from $34 \%$ to $54 \%$ ), Fe (from $31 \%$ to 33\%) and $\mathrm{Cu}$ (from $3 \%$. We obtained similar results as well found that compost application increased the soil total $\mathrm{N}$ and the available $\mathrm{K}, \mathrm{Fe}, \mathrm{Zn}$, and $\mathrm{Mn}$ concentrations, whereas the available $\mathrm{Cu}$ decreased and the available soil $\mathrm{P}$ was not affected (Allison, 1965). The effect of three types of tillage (disc, DP; sweep, SW; and mouldboard, MP) and five $\mathrm{N}$ application rates $(0,45,90,135$, and $180 \mathrm{~kg}$ ha-1) on macronutrients in soil and wheat (Triticum aestivum L.) tissues grown in a winter wheat-summer fallow rotation were studied The experiment included three types of tillage (disc, DP; sweep, SW; and mouldboard; MP) and five $\mathrm{N}$ application rates $(0,45,90$, 135 , and $180 \mathrm{~kg}$ ha-1). Soil and tissue samples were analysed for the concentration of total $\mathrm{N}$, $\mathrm{S}$, and $\mathrm{C}$, Mehlich III extractable $\mathrm{P}, \mathrm{K}, \mathrm{Mg}, \mathrm{Ca}$ in the soil, and the total concentration of the same nutrients in wheat tissue. Soil N concentration was significantly greater under DP $(1.10 \mathrm{~g}$ $\mathrm{kg}-1)$ than under MP (1.03 g kg-1). The P concentration in upper $20 \mathrm{~cm}$ soil depth increased with increased $\mathrm{N}$ rates. Comparison of experiment plots to a nearby-undisturbed pasture revealed a decline of P (32\%), SOC (34\%), Mg (77\%), and Ca (86\%) in the top $10 \mathrm{~cm}$ soil depth. Bread in Yemen is the staple food, produced in different kinds from local and imported wheat, most of which is not subjected to micro-elemental analysis. Fortunately, $\mathrm{Fe}, \mathrm{Cu}, \mathrm{Mn}$, $\mathrm{Zn}, \mathrm{Co}, \mathrm{Cd}$, and $\mathrm{Pb}$ micro-elements in samples of wheat grains produced locally from different cultivated regions in Yemen as well as those imported from the USA and Austria were generally within the permissible levels except for cadmium (Allison, 1965). 
Table 7. Soil character distinction by LSD.

\begin{tabular}{|c|c|c|c|c|c|c|c|}
\hline Entries & $\begin{array}{l}\partial^{0} \\
0^{m} \\
U_{\tilde{J}}^{\circ}\end{array}$ & 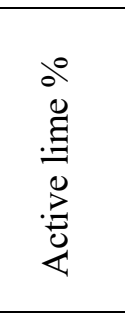 & 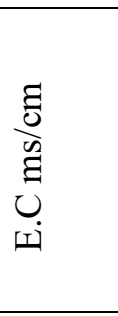 & 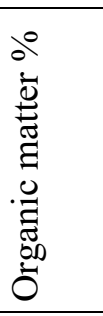 & 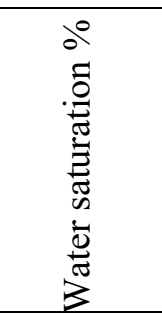 & 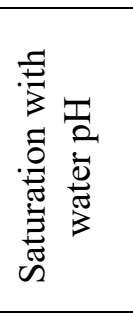 & 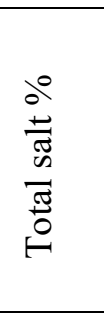 \\
\hline $\begin{array}{l}\text { Population-1 } \\
\text { Karabük-Safranbolu }\end{array}$ & $0.80^{\mathrm{h}^{*}}$ & $0.40^{\mathrm{h}}$ & $0.46^{\mathrm{a}}$ & $1.33^{\mathrm{c}}$ & $127.40^{\mathrm{a}}$ & $7.24^{\mathrm{b}}$ & $0.06^{\mathrm{a}}$ \\
\hline $\begin{array}{l}\text { Population-2 } \\
\text { Kastamonu-İhsangazi }\end{array}$ & $59.23^{\mathrm{a}}$ & $29.63^{a}$ & $0.59^{\mathrm{a}}$ & $3.78^{\mathrm{a}}$ & $69.17^{\mathrm{e}}$ & $7.23^{\mathrm{b}}$ & $0.04^{\mathrm{a}}$ \\
\hline $\begin{array}{l}\text { Population-3 } \\
\text { Kastamonu-İhsangazi }\end{array}$ & $16.63^{\mathrm{d}}$ & $8.43^{\mathrm{d}}$ & $0.60^{\mathrm{a}}$ & $2.62^{\mathrm{b}}$ & $96.69^{b}$ & $7.51^{\mathrm{a}}$ & $0.04^{\mathrm{a}}$ \\
\hline $\begin{array}{l}\text { Population-4 } \\
\text { Kastamonu-İhsangazi }\end{array}$ & $5.21^{\mathrm{f}}$ & $2.63^{\mathrm{f}}$ & $0.53^{\mathrm{a}}$ & $2.58^{\mathrm{b}}$ & $91.47^{\mathrm{b}}$ & $7.60^{\mathrm{a}}$ & $0.04^{\mathrm{a}}$ \\
\hline $\begin{array}{l}\text { Population-5 } \\
\text { Samsun-Ladik }\end{array}$ & $2.98^{\mathrm{g}}$ & $1.53^{\mathrm{g}}$ & $0.60^{\mathrm{a}}$ & $1.72^{\mathrm{b}}$ & $72.60^{\mathrm{d}}$ & $7.36^{\mathrm{b}}$ & $0.03^{\mathrm{a}}$ \\
\hline $\begin{array}{l}\text { Population-6 } \\
\text { Sinop-Durağan }\end{array}$ & $1.21^{\mathrm{h}}$ & $0.63^{\mathrm{g}}$ & $0.42^{\mathrm{a}}$ & $2.55^{\mathrm{b}}$ & $59.43^{\mathrm{f}}$ & $7.17^{\mathrm{b}}$ & $0.03^{\mathrm{a}}$ \\
\hline $\begin{array}{l}\text { Population-7 } \\
\text { Bolu-Seben } \\
\end{array}$ & $36.17^{\mathrm{b}}$ & $18.20^{\mathrm{b}}$ & $0.44^{\mathrm{a}}$ & $0.65^{\mathrm{c}}$ & $84.77^{c}$ & $7.61^{\mathrm{a}}$ & $0.03^{\mathrm{a}}$ \\
\hline $\begin{array}{l}\text { Population-8 } \\
\text { Sinop-Durağan }\end{array}$ & $0.04^{\mathrm{i}}$ & $0.01^{\mathrm{h}}$ & $0.47^{\mathrm{a}}$ & $2.37^{\mathrm{b}}$ & $77.00^{\mathrm{d}}$ & $6.22^{\mathrm{d}}$ & $0.03^{\mathrm{a}}$ \\
\hline $\begin{array}{l}\text { Population-9 } \\
\text { Bolu-Seben } \\
\end{array}$ & $19.23^{\mathrm{c}}$ & $9.63^{\mathrm{c}}$ & $0.47^{\mathrm{a}}$ & $0.93^{\mathrm{c}}$ & $79.23^{c}$ & $7.55^{\mathrm{a}}$ & $0.03^{\mathrm{a}}$ \\
\hline Bezostaja-1 & $14.07^{\mathrm{e}}$ & $7.05^{\mathrm{e}}$ & $0.46^{\mathrm{a}}$ & $1.81^{\mathrm{b}}$ & $75.50^{d}$ & $6.48^{\mathrm{c}}$ & $0.04^{\mathrm{a}}$ \\
\hline Kunduru-1149 & $14.22^{\mathrm{e}}$ & $7.15^{\mathrm{e}}$ & $0.49^{\mathrm{a}}$ & $1.87^{\mathrm{b}}$ & $77.72^{c}$ & $6.57^{\mathrm{c}}$ & $0.04^{\mathrm{a}}$ \\
\hline LSD 0.05 & 0.75 & 1.05 & 0.19 & 0.96 & 7.40 & 0.24 & 0.12 \\
\hline
\end{tabular}

${ }^{*}$ The same letter in the same column describes no difference otherwise there is a difference.

\subsection{Soil Structure}

Analysis of variance (Table 6) showed that $\mathrm{CaCO}_{3} \%$, active lime $\%, \mathrm{~K}_{2} \mathrm{O}$, organic matter $\%$, $\mathrm{P}_{2} \mathrm{O}_{5}$, water saturation, and saturation with water $\mathrm{pH}$ were statistically significant $(0.05)$, while $\mathrm{EC}$ and total salt \% were not.

Large differences existed for lime amount among soil samples (Table 7). Kastamonu İhsangazi (Population-2) had the highest lime amount (59.23 \%), while Sinop Durağan (Population-8) had the lowest (0.04). Active lime also differed greatly: Kastamonu İhsangazi (Population-2) soil had the highest (29.63\%), while Sinop Durağan (Population-8) had the lowest $(0.01 \%)$. Kastamonu İhsangazi (Population-3) and Samsun Ladik (Population-5) soil samples had the highest E.C. $(0.60 \mathrm{~ms} / \mathrm{cm})$, while Sinop Durağan (Population-6) soil sample had the lowest $(0.42 \mathrm{~ms} / \mathrm{cm})$. Kastamonu İhsangazi (Population-2) had the highest organic matter (3.78 \%); Bolu Seben (Population-7) soil sample had the lowest (0.65\%). Karabük Safranbolu (Population-1) had the highest water saturation (127.40 \%); whereas Sinop Durağan (Population-6) soil sample had the lowest (59.43 \%). Kastamonu İhsangazi (Population-4) had the highest water $\mathrm{pH}$ (7.60); on the other hand, Sinop Durağan (Population-8) soil sample had the lowest (6.22). Karabük Safranbolu (Population-1) had the highest total salt (0.06 \%); whereas Samsun Ladik (Population-5), Sinop Durağan (Population-6), Bolu Seben (Population-7), Sinop Durağan (Population-8) and Bolu Seben (Population-9) soil samples had the lowest $(0.03 \%)$. 


\subsection{Wheat Grain and Soil Structure Correlations}

Probability theory and correlation in statistics indicate the strength and direction of the relationship between two independent variables. In widespread statistical use, the correlation shows how far the variables are away from independence. We, therefore, evaluated the results obtained from wheat grain and soil samples in the study with the correlation analysis methods as well. In this way, there existed some relationships among macro-micro elements and other properties presented as follows:

Correlations among eleven wheat entries for macro-micro elements provided a highly significant relationship for $\mathrm{N}-\mathrm{Cu}(0.926), \mathrm{P}-\mathrm{Mn}(0.838)$, and $\mathrm{P}-\mathrm{K}(0.788)$ and a significant relationship for $\mathrm{Zn}-\mathrm{Mn}$ (0.634), Fe-Mn (0.532), and K-Mn (0.512). No relationships existed for N-Mn (0.400), N-Zn (0.219), N-Fe (0.449), N-P (0.049), P-Zn (0.218), P-Fe (0.389), P-Cu (0.026), K-Zn (0.275), K-Fe (0.424), Cu-Mn (0.318), Cu-Zn (0.145), Cu-Fe (0.409), and Fe-Zn (0.380). Relationships between K-N (-0.229) and $\mathrm{Cu}-\mathrm{K}(-0.116)$ were, on the other hand, negative (Table 8).

Table 8. Correlations among macro-micro elements for wheat grain.

\begin{tabular}{lcccccc}
\hline Characters & $\begin{array}{c}\mathrm{N} \\
(\mathrm{mg} / \mathrm{kg})\end{array}$ & $\begin{array}{c}\mathrm{P} \\
(\mathrm{mg} / \mathrm{kg})\end{array}$ & $\begin{array}{c}\mathrm{K} \\
(\mathrm{mg} / \mathrm{kg})\end{array}$ & $\begin{array}{c}\mathrm{Cu} \\
(\mathrm{mg} / \mathrm{kg})\end{array}$ & $\begin{array}{c}\mathrm{Fe} \\
(\mathrm{mg} / \mathrm{kg})\end{array}$ & $\begin{array}{c}\mathrm{Zn} \\
(\mathrm{mg} / \mathrm{kg})\end{array}$ \\
\hline $\mathrm{Mn}(\mathrm{mg} / \mathrm{kg})$ & 0.400 & $0.838^{* *}$ & 0.512 & 0.318 & 0.532 & $0.634^{*}$ \\
$\mathrm{Zn}(\mathrm{mg} / \mathrm{kg})$ & 0.219 & 0.218 & 0.275 & 0.145 & 0.380 & - \\
$\mathrm{Fe}(\mathrm{mg} / \mathrm{kg})$ & 0.449 & 0.389 & 0.424 & 0.409 & - & \\
$\mathrm{Cu}(\mathrm{mg} / \mathrm{kg})$ & $0.926^{* *}$ & 0.026 & -0.116 & - & & \\
$\mathrm{K}(\mathrm{mg} / \mathrm{kg})$ & -0.229 & $0.788^{* *}$ & - & & & \\
$\mathrm{P}(\mathrm{mg} / \mathrm{kg})$ & 0.049 & - & & & & \\
${ }^{*}$ Significan & & & & &
\end{tabular}

${ }^{*}$ Significant at $0.05,{ }^{* *}$ significant at 0.01 .

In order to reduce the amount of trace metals such as cadmium in human food, a study attempted to predict the trace metal composition of cereal grains from well-chosen topsoil variables (Anonymous, 2016) They compared metal contents in grain and in topsoil samples. 198 samples of grains of winter wheat were collected from paired topsoil and crop surveys in the northern half of France. Canonical correlation analysis including multiple linear regression was used to study relationships between soil and grain data. Their findings showed an excellent regression model for grain $\mathrm{Cd}$ with a small number of topsoil variables, thus allowing an accurate prediction for winter wheat grains. Practically, farmers can use the prediction model to predict $\mathrm{Cd}$ and other micro elements such as $\mathrm{Zn}, \mathrm{Fe}$, etc. In another study Anonymous, 2013), (1) the effects of genotype, environment, and their interactions on the oil content (OC), protein content (PC), and grain yield (GY) of 25 varieties of winter wheat, (2) the correlations among these traits in different environments, and (3) the effects of different climatic variables and their interactions with wheat genotypes were studied for the examined traits. A significant positive correlation between wheat bran OC and GY existed, while highly significant negative correlations between PC and GY existed in three out of six environments.

\subsection{Quality Character Correlations Among Wheat Grains}

Correlation constants (r) among eleven wheat grains indicated the highest positive significant relationship between carbohydrate-starch $\left(0.975^{* *}\right)$. Moreover, positive highly significant relationships were prevalent between energy-starch $\%\left(0.817^{* *}\right)$, energy-carbohydrate $\left(0.762^{* *}\right)$, and crude cellulose-crude protein $\left(0.609^{* *}\right)$. That is, the increase of one lead to the increase of the other. Insignificant relationships between raw oil-energy $(0.565), 1000 \mathrm{KW}$ crude cellulose (0.504), raw ash-hectolitre (0.413), carbohydrate-raw oil (0.403), starch \% - raw 
oil (0.378), crude protein-hectolitre $(0.353)$, total sugar-hectolitre $(0.351), 1000 \mathrm{KW}$-crude protein $(0.177), 1000 \mathrm{KW}$-energy $(0.163)$, total sugar-raw oil $(0.160)$, total sugar-energy (0.154), carbohydrate-total sugar (0.121), crude protein-raw ash (0.109), $1000 \mathrm{KW}$ carbohydrate (0.047), and raw oil-raw ash (0.024) existed. We also obtained negative insignificant correlation between total sugar-starch \% (-0.009), crude protein-total sugar (0.069), crude cellulose-hectolitre (-0.097), $1000 \mathrm{KW}$-hectolitre (-0.102), crude protein-energy $(-0.137)$, raw ash-total sugar (-0.139), raw ash-crude cellulose (-0.160), raw oil-hectolitre (0.194), $1000 \mathrm{KW}$-starch\% (-0.234), $1000 \mathrm{KW}$-raw oil (-0.235), $1000 \mathrm{KW}$-raw ash (-0.245), energy-crude cellulose (-0.248), crude protein-raw oil (-0.304), raw ash-carbohydrate $(-0.340)$, crude cellulose-raw oil (-0.346), energy-raw ash (-0.346), crude cellulose-starch \% (-0.379), raw ash-starch \% (-0.380), crude cellulose-carbohydrate (-0.531), $1000 \mathrm{KW}$-total sugar ($0.544)$, energy-hectolitre (-0.545), crude protein-starch\% (-0.605), hectolitre-carbohydrate ($0.626)$, crude cellulose-total sugar $(-0.687)$, hectolitre-starch \% (-0.691), and crude proteincarbohydrate (-0.706). That is, the increase in one cause decrease in the other (Table 9). As known, correlation coefficient ( $\mathrm{r}$ ) changes between +1 and -1 and shows non-linear relationships between two traits under the study. Data provided were significant between only some traits such as carbohydrate-starch $\left(0.975^{* *}\right)$, energy-starch $\%\left(0.817^{* *}\right)$, energycarbohydrate $\left(0.762^{* *}\right)$, and crude cellulose-crude protein $\left(0.609^{* *}\right)$. In a semi-arid environment with agronomical and quality traits in durum wheat (Triticum durum) germplasm revealed a significant genotypical variance for all traits measured. The environment (year) variance was significant for all morphological and quality parameters. Genotype $\mathrm{x}$ environment interaction was significant for all traits except for biological yield and 1000 grain weight. Analysis of Pearson's correlation showed that most agronomical traits are inversely correlated with quality parameters.

Table 9. Quality character correlations among wheat grains.

\begin{tabular}{|c|c|c|c|c|c|c|c|c|c|}
\hline Characters & $\frac{3}{8} \overparen{8}$ & $\begin{array}{l}. \\
0 \\
0 \\
0 \\
0 \\
0 \\
0 \\
0 \\
己 \\
0\end{array}$ & 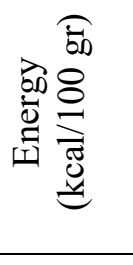 & 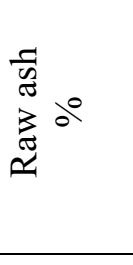 & 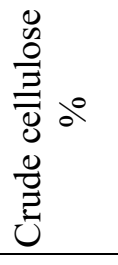 & 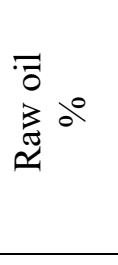 & 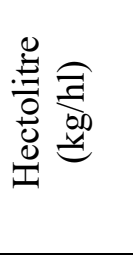 & 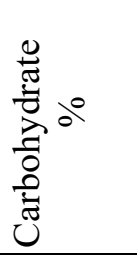 & 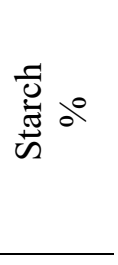 \\
\hline Total sugar $\%$ & -0.544 & -0.069 & 0.154 & -0.139 & -0.687 & 0.160 & 0.351 & 0.121 & -0.009 \\
\hline Starch \% & -0.234 & -0.605 & $0.817^{* *}$ & -0.380 & -0.379 & 0.378 & -0.691 & $0.975^{* *}$ & - \\
\hline Carbohydrate \% & 0.047 & -0.706 & $0.762^{* *}$ & -0.340 & -0.531 & 0.403 & -0.626 & - & \\
\hline Hectolitre $(\mathrm{kg} / \mathrm{hl})$ & -0.102 & 0.353 & -0.545 & 0.413 & -0.097 & -0.194 & - & & \\
\hline Raw oil \% & -0.235 & -0.304 & 0.565 & 0.024 & -0.346 & - & & & \\
\hline Crude cellulose $\%$ & 0.504 & $0.609^{*}$ & -0.248 & -0.160 & - & & & & \\
\hline Raw ash \% & -0.245 & 0.109 & -0.346 & - & & & & & \\
\hline Energy (kcal/100 gr) & 0.163 & -0.137 & - & & & & & & \\
\hline Crude protein $\%$ & 0.177 & - & & & & & & & \\
\hline
\end{tabular}

* Significant at $0.05,{ }^{* *}$ significant at 0.01 . 


\subsection{Correlations Among Soil Characteristics}

\subsubsection{Correlations among soil macro-micro elements}

Correlation constants (r) among 11 soil samples for macro-micro element contents showed highly significant relationship between $\mathrm{P}_{2} \mathrm{O}_{5}-\mathrm{Zn}(0.910)$, Fe-Mn (0.802), Total $\mathrm{N} \%-\mathrm{P}_{2} \mathrm{O}_{5}$ $(0,783)$, and total $\mathrm{N} \%-\mathrm{Mn}(0.736)$. The significant relationships existed between total $\mathrm{N} \%-\mathrm{Zn}$ (0.725), Cu-Mg (0.704), and $\mathrm{Cu}-\mathrm{Ca}(0.608)$. Significant relationships were prevalent between $\mathrm{Na}-\mathrm{Ca}$ (0.554), $\mathrm{P}_{2} \mathrm{O}_{5}-\mathrm{Mn}$ (0.494), Zn-Mn (0.458), Total N\%-Cu (0.433), $\mathrm{P}_{2} \mathrm{O}_{5}$-Fe (0.414), FeZn (0.405), Total N\%-Fe (0.402), K-Fe (0.390), Ca-Mg (0.355), K-Mn (0.338), Fe-Mg (0.282), $\mathrm{K}-\mathrm{Mg}$ (0.251), K-Zn (0.241), Total N\%-K (0.144), Cu-Mn (0.117), $\mathrm{P}_{2} \mathrm{O}_{5}-\mathrm{Cu}$ (0.113), K-Cu (0.113), K-Ca (0.072), Na-Cu (0.062), Na-K (0.054), Cu-Zn (0.054), Total N\%-Na (0.019), and $\mathrm{Na}-\mathrm{Mn}(0.018)$. The interaction between these values is not significant. We obtained negative results between $\mathrm{P}_{2} \mathrm{O}_{5}-\mathrm{K}(-0.006)$, $\mathrm{Mn}-\mathrm{Mg}(-0.006)$, $\mathrm{Fe}-\mathrm{Cu}(-0.024)$, Total N\%-Mg (-0.033), $\mathrm{P}_{2} \mathrm{O}_{5}-\mathrm{Mg}(-0.117), \mathrm{Zn}-\mathrm{Mg}$ (-0.137), Total N\%-Ca (-0.149), Na-Mg (-0.216), Na-Zn (-0.289), $\mathrm{Na}-\mathrm{Fe}(-0.299)$, Ca-Mn (-0.321), $\mathrm{P}_{2} \mathrm{O}_{5}-\mathrm{Na}(-0.401), \mathrm{P}_{2} \mathrm{O}_{5}-\mathrm{Ca}(-0.479), \mathrm{Ca}-\mathrm{Zn}(-0.497)$, and $\mathrm{Fe}-$ $\mathrm{Ca}(-0.533)$. The results we get are negative and there is a negative relationship between them. The increase in one cause the other to decline (Table 10).

A comparison of macro- and microelement concentrations in the whole grain of four Triticum species revealed that five macro- and fifteen microelements in the whole grain of emmer, einkorn, spelt, and two common wheat species differed for $\mathrm{P}, \mathrm{Mg}, \mathrm{Zn}, \mathrm{Fe}, \mathrm{Mn}, \mathrm{Na}, \mathrm{Cu}$, $\mathrm{Sr}, \mathrm{Rb}$, and Mo (Pekcan \& Köksal, 2006). The grain of all hulled wheats, compared with common wheat, contained significantly more $\mathrm{Zn} \mathrm{(34-54 \% ),} \mathrm{Fe} \mathrm{(31-33 \% ),} \mathrm{and} \mathrm{Cu}(3-28 \%)$. In most cases, there were no relationships between the concentrations of the analysed elements, except for significant positive correlations between the levels of $\mathrm{Fe}, \mathrm{Zn}$, and $\mathrm{Mn}$, in $T$. monococcum L. subsp. monococcum and T. dicoccum Schrank. A strong correlation between $\mathrm{Zn}, \mathrm{Fe}$, and $\mathrm{Mn}$ could have implied positive views for wheat quality breeding. The metallomic profile related to micro $\mathrm{Zn}, \mathrm{Fe}, \mathrm{Cu}, \mathrm{Mn}, \mathrm{Ni}$ and $\mathrm{Cr}$ and macro $\mathrm{Ca}, \mathrm{Mg}$ and $\mathrm{K}$ and toxic trace elements $(\mathrm{Cd}$ and $\mathrm{Pb})$ was obtained by ICP-AES analysis in a large set of tetraploid wheat genotypes (Triticum turgidum subsp. durum Desf.), which were grown in two different experimental fields. The significantly higher content of $\mathrm{Mg}$ (among the macronutrients) and the highest levels of $\mathrm{Mn}, \mathrm{Fe}$ and $\mathrm{Zn}$ (among the micronutrients) existed for wild accessions with respect to durum cultivars. Moreover, the former genotypes were also the ones with the lowest level of accumulation of the trace toxic elements, Cd. According to the performed statistical analyses, the wild accessions also appeared to be less influenced by different environmental conditions. This is in accord with literature data, indicating the superiority of "old" with respect to modern wheat cultivars for mineral content.

\subsection{Correlations Among Soil Characteristics}

\subsubsection{Correlations among soil macro-micro elements}

Correlation constants (r) among 11 soil samples for macro-micro element contents showed highly significant relationships between $\mathrm{P}_{2} \mathrm{O}_{5}-\mathrm{Zn}\left(0.910^{* *}\right)$, Fe-Mn $\left(0.802^{* *}\right)$, Total $\mathrm{N} \%-\mathrm{P}_{2} \mathrm{O}_{5}$ $\left(0.783^{* *}\right)$, and total $\mathrm{N} \%-\mathrm{Mn}\left(0.736^{* *}\right)$. The significant linear relationships existed between total $\mathrm{N} \%-\mathrm{Zn}\left(0.725^{*}\right), \mathrm{Cu}-\mathrm{Mg}\left(0.704^{*}\right)$, and $\mathrm{Cu}-\mathrm{Ca}(0.608)$. Higher but insignificant relationships were prevalent between Na-Ca (0.554), $\mathrm{P}_{2} \mathrm{O}_{5}-\mathrm{Mn}(0.494), \mathrm{Zn}-\mathrm{Mn}(0.458)$, Total N \%-Cu (0.433), $\mathrm{P}_{2} \mathrm{O}_{5}-\mathrm{Fe}(0.414), \mathrm{Fe}-\mathrm{Zn}(0.405)$, and total $\mathrm{N} \%$-Fe (0.402). We obtained insignificant negative results between $\mathrm{P}_{2} \mathrm{O}_{5}-\mathrm{K}(-0.006), \mathrm{Mn}-\mathrm{Mg}(-0.006), \mathrm{Fe}-\mathrm{Cu}(-0.024)$, total $\mathrm{N} \%-\mathrm{Mg}(-$ 0.033), $\mathrm{P}_{2} \mathrm{O}_{5}-\mathrm{Mg}(-0.117), \mathrm{Zn}-\mathrm{Mg}(-0.137)$, total N \%-Ca (-0.149), Na-Mg (-0.216), Na-Zn ($0.289)$, Na-Fe (-0.299), Ca-Mn (-0.321), $\mathrm{P}_{2} \mathrm{O}_{5}-\mathrm{Na}(-0.401), \mathrm{P}_{2} \mathrm{O}_{5}-\mathrm{Ca}(-0.479), \mathrm{Ca}-\mathrm{Zn}(-0.497)$, and $\mathrm{Fe}-\mathrm{Ca}(-0.533)$ (Table 10). 
Table 10. Correlations among soil macro-micro elements.

\begin{tabular}{|c|c|c|c|c|c|c|c|c|c|}
\hline Characters & $\begin{array}{l}\text { Total N } \\
\%\end{array}$ & $\begin{array}{l}\mathrm{P}_{2} \mathrm{O}_{5} \\
(\mathrm{~kg} / \mathrm{da})\end{array}$ & $\begin{array}{c}\mathrm{Na} \\
(\mathrm{mg} / \mathrm{kg})\end{array}$ & $\begin{array}{c}\mathrm{K} \\
(\mathrm{mg} / \mathrm{kg})\end{array}$ & $\begin{array}{c}\mathrm{Fe} \\
(\mathrm{mg} / \mathrm{kg})\end{array}$ & $\begin{array}{c}\mathrm{Cu} \\
(\mathrm{mg} / \mathrm{kg})\end{array}$ & $\begin{array}{c}\mathrm{Ca} \\
(\mathrm{mg} / \mathrm{kg})\end{array}$ & $\begin{array}{c}\mathrm{Zn} \\
(\mathrm{mg} / \mathrm{kg})\end{array}$ & $\begin{array}{c}\mathrm{Mn} \\
(\mathrm{mg} / \mathrm{kg})\end{array}$ \\
\hline $\operatorname{Mg}(\mathrm{mg} / \mathrm{kg})$ & -0.033 & -0.117 & -0.216 & 0.251 & 0.282 & $0.704^{*}$ & 0.355 & -0.137 & -.006 \\
\hline $\mathrm{Mn}(\mathrm{mg} / \mathrm{kg})$ & $0.736^{* *}$ & 0.494 & 0.018 & 0.338 & $0.802^{* *}$ & 0.117 & -0.321 & 0.458 & - \\
\hline$\overline{\mathrm{Zn}(\mathrm{mg} / \mathrm{kg})}$ & $0.725^{*}$ & $0.910^{* * *}$ & -0.289 & 0.241 & 0.405 & 0.054 & -0.497 & - & \\
\hline $\mathrm{Ca}(\mathrm{mg} / \mathrm{kg})$ & -0.149 & -0.479 & 0.554 & 0.072 & -0.533 & $0.608^{*}$ & - & & \\
\hline $\mathrm{Cu}(\mathrm{mg} / \mathrm{kg})$ & 0.433 & 0.113 & 0.062 & 0.113 & -0.024 & - & & & \\
\hline $\mathrm{Fe}(\mathrm{mg} / \mathrm{kg})$ & 0.402 & 0.414 & -0.299 & 0.390 & - & & & & \\
\hline$\overline{\mathrm{K}}(\mathrm{mg} / \mathrm{kg})$ & 0.144 & -0.006 & 0.054 & - & & & & & \\
\hline $\mathrm{Na}(\mathrm{mg} / \mathrm{kg})$ & 0.019 & -0.401 & - & & & & & & \\
\hline $\mathrm{P}_{2} \mathrm{O}_{5}(\mathrm{~kg} / \mathrm{da})$ & $0.783^{* *}$ & - & & & & & & & \\
\hline
\end{tabular}

* Significant at $0.05,{ }^{* *}$ significant at 0.01 .

A research (Emmanuel et al., 2014) to study the distribution of available macronutrients $(\mathrm{N}$, $\mathrm{P}, \mathrm{K}$ and $\mathrm{S}$ ) and micronutrients (Fe, $\mathrm{Mn}, \mathrm{Zn}, \mathrm{Cu}$ ) and their relationship with some physicochemical properties of soil of different blocks showed that values of the organic $\mathrm{C}$, alkaline $\mathrm{KMnO} 4$, extractable $\mathrm{N}$, Olsen's $\mathrm{P}$, neutral ammonium acetate, extractable $\mathrm{K}$ and $\mathrm{CaCl}_{2}$, and extractable $\mathrm{S}$ in the district ranged between $0.13-1.64 \%, 125.44-338.68 \mathrm{~kg} \mathrm{~N}$ ha-1, 7.34-76.70 $\mathrm{kg} \mathrm{P}_{2} \mathrm{O}_{5}$ ha-1 , 66.08-271.04 $\mathrm{kg} \mathrm{K} 2 \mathrm{O}$ ha-1 and 2.41-42.5 S ppm, respectively. The values of DTPA extractable Fe, $\mathrm{Mn}, \mathrm{Zn}$ and $\mathrm{Cu}$ ranged between 12.42-54.06, 0.96-22.06, 0.26-4.64 and 0.59-7.62 ppm, respectively. Macronutrients in general were non-significantly and negatively correlated with $\mathrm{pH}$, clay and sand, but positively correlated with organic $\mathrm{C}$ and silt. However, micronutrients in general were non-significantly and positively correlated with $\mathrm{pH}$, organic $\mathrm{C}$ and clay and negatively with silt and sand. Phosphorus $\left(-0.456^{*}\right)$ and $\mathrm{Fe}\left(-0.533^{* *}\right)$ showed significantly negative relationship with $\mathrm{pH}$, while phosphorus and $\mathrm{Zn}$ had significantly positive relation with organic $\mathrm{C}\left(0.335^{*}, 0.305^{*}\right)$ and with clay $\left(-0.378^{*}, 0.372^{*}\right)$. The soils of the district were low in nitrogen, sufficient in phosphorus, potassium, and sulphur except for Sitarganj, Jaspur and Bazpur blocks were low in $\mathrm{K}$ and Rudrapur block was low in $\mathrm{S}$; however, micronutrients ( $\mathrm{Fe}, \mathrm{Mn}, \mathrm{Zn}$, and $\mathrm{Cu}$ ) were much higher than the critical level in the district. As mentioned above, a study, while comparing macro- and microelement concentrations in the whole grain of four Triticum species, all grown under identical environmental conditions, indicated that the concentrations of the investigated elements were a species-specific character.

\subsection{Correlations among Other Soil Characteristics}

Correlation constants among 11 soil samples revealed highly significant relationships between $\mathrm{CaCO}_{3} \%$ - active lime $\left(1.000^{* *}\right)$, water saturation-total salt \% $\left(0.829^{* *}\right) ; \mathrm{CaCO}_{3} \%-\mathrm{K}_{2} \mathrm{O}$ $\left(0.750^{* *}\right)$, and active lime- $\mathrm{K}_{2} \mathrm{O}\left(0.749^{* *}\right)$. EC-organic matter \% $(0.518)$, EC- $\mathrm{K}_{2} \mathrm{O}(0.438), \mathrm{K}_{2} \mathrm{O}$ - organic matter $\%(0.408), \mathrm{K}_{2} \mathrm{O}$-total salt $\%(0.400), \mathrm{EC}-\mathrm{Ph}(0.288)$, active lime $\%$ - EC (0.284), $\mathrm{CaCO}_{3} \%$ - EC (0.283), $\mathrm{K}_{2} \mathrm{O}$-saturation with water $\mathrm{pH}(0.252), \mathrm{CaCO}_{3} \%-\mathrm{pH}(0.249), \mathrm{CaCO}_{3}$ $\%$ - organic matter \% (0.255), active lime \%-organic matter \% (0.253), active lime \%- $\mathrm{pH}$ (0.251), $\mathrm{pH}$ - water saturation \% (0.249), $\mathrm{K}_{2} \mathrm{O}$ - water saturation (0.228), $\mathrm{pH}$ - total salt \% (0.143), EC-total salt \% (0.116), and organic matter \% - total salt \% (0.086)displayed higher but insignificant relationships. Negative insignificant correlation occurred between water saturation-EC (-0.001), $\mathrm{CaCO}_{3} \%$-total salt $\%(-0.062)$, active lime $\%$ - total salt $\%(-0.062), \mathrm{pH}-$ organic matter $\%(-0.154)$, water saturation- $\mathrm{CaCO}_{3} \%(-0.224)$, water saturation-active lime $\%$ $(-0.224)$, and water saturation- organic matter \% (-0.310) (Table 11). 
Table 11. Correlations among other soil characteristics.

\begin{tabular}{|c|c|c|c|c|c|c|c|}
\hline Characters & 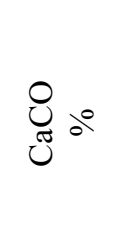 & 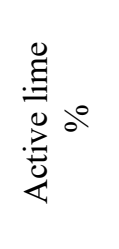 & 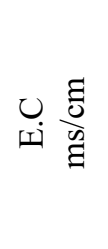 & 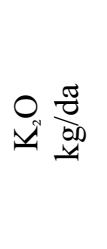 & 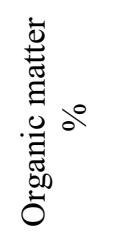 & 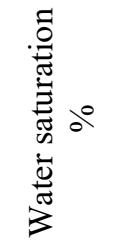 & 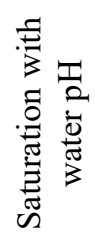 \\
\hline Total salt $\%$ & -0.062 & -0.062 & 0.116 & 0.400 & 0.086 & $0.829^{* *}$ & 0.143 \\
\hline $\begin{array}{l}\text { Saturation with } \\
\text { water } \mathrm{pH}\end{array}$ & 0.249 & 0.251 & 0.288 & 0.252 & -0.154 & 0.249 & - \\
\hline Water saturation \% & -0.224 & -0.224 & -0.001 & 0.228 & -0.310 & - & \\
\hline Organic matter \% & 0.255 & 0.253 & 0.518 & 0.408 & - & & \\
\hline $\mathrm{K}_{2} \mathrm{O} \mathrm{kg} / \mathrm{da}$ & $0.750^{* *}$ & $0.749^{* *}$ & 0.438 & - & & & \\
\hline E.C ms/cm & 0.283 & 0.284 & - & & & & \\
\hline Active lime $\%$ & $1.000^{* *}$ & - & & & & & \\
\hline
\end{tabular}

* Significant at $0.05,{ }^{* *}$ significant at 0.01 .

\subsection{Grain and Soil Characteristics Dendrogram}

The dendrogram is a kind of clustering technique. A dendrogram is a diagram that shows the hierarchical relationship between objects. It is most created as an output from hierarchical clustering. The main use of a dendrogram is to work out the best way to allocate objects to clusters (Figure 1). Clustering analysis, on the other hand, is the process of separating information in a data set into groups according to a certain proximity criterion. Each of these groups is called a 'cluster'. The process is called clustering. The simplest definition of clustering is to distinguish data elements with similar characteristics. We, here, preferred dendrogram to establish the proximity and distance relationship of wheat populations and soil samples.

The first main group had two subgroups, while Population-4 stood alone. The first subgroup in the first main group was limited to only Population-1, Population-3, Population-8, and Kunduru-1149. The second main group was also divided into two subgroups. From these groups, the first subgroup had Population-7 and Population-9, and the second subgroup did Population-5, Population-6, Population-2, and Bezostaja-1. Population-4 was very different from the other populations for macro-micro element content and nutritional values. Population4 was from Enbiya Village, İhsangazi, Kastamonu. It was too different from the others. Factors affecting might have been seed quality and quantity, cultivation, sowing time, harvest season, abandonment, soil, climatic conditions, and irrigation.

\subsection{Soil Characteristics by Dendrogram}

A dendrogram based on the average of $\mathrm{CaCO}_{3}$, active lime, $\mathrm{EC}, \mathrm{K}_{2} \mathrm{O}$, organic matter, $\mathrm{P}_{2} \mathrm{O}_{5}$, water saturation, saturation with water $\mathrm{pH}$, total salt, total $\mathrm{N}, \mathrm{Na}, \mathrm{K}, \mathrm{Fe}, \mathrm{Cu}, \mathrm{Ca}, \mathrm{Zn}, \mathrm{Mn}$, and $\mathrm{Mg}$ in 11 soil samples formed two main groups (Figure2). The first main group consisted of five populations and the second main group consisted of two subgroups. The first main group was limited to only Population-2, Bezostaja-1, Population-7, Population-6, and Population-8. The first subgroup in the second main group consisted of Population-3 and Population-5, and the second subgroup obtained Population-9, Kunduru-1149, Population-1, and Population-4. 
Figure 1. Dendogram for 11 entries of five einkorn, four emmer, one durum, and one bread wheat based on the averages of $1000 \mathrm{KW}$, crude protein, energy, raw ash, crude cellulose, raw oil, hectolitre, carbohydrate, starch \%, total sugar \%, macro elements ( $\mathrm{N}, \mathrm{P}, \mathrm{K})$, and micro elements ( $\mathrm{Fe}, \mathrm{Cu}, \mathrm{Zn}, \mathrm{Mn})$.

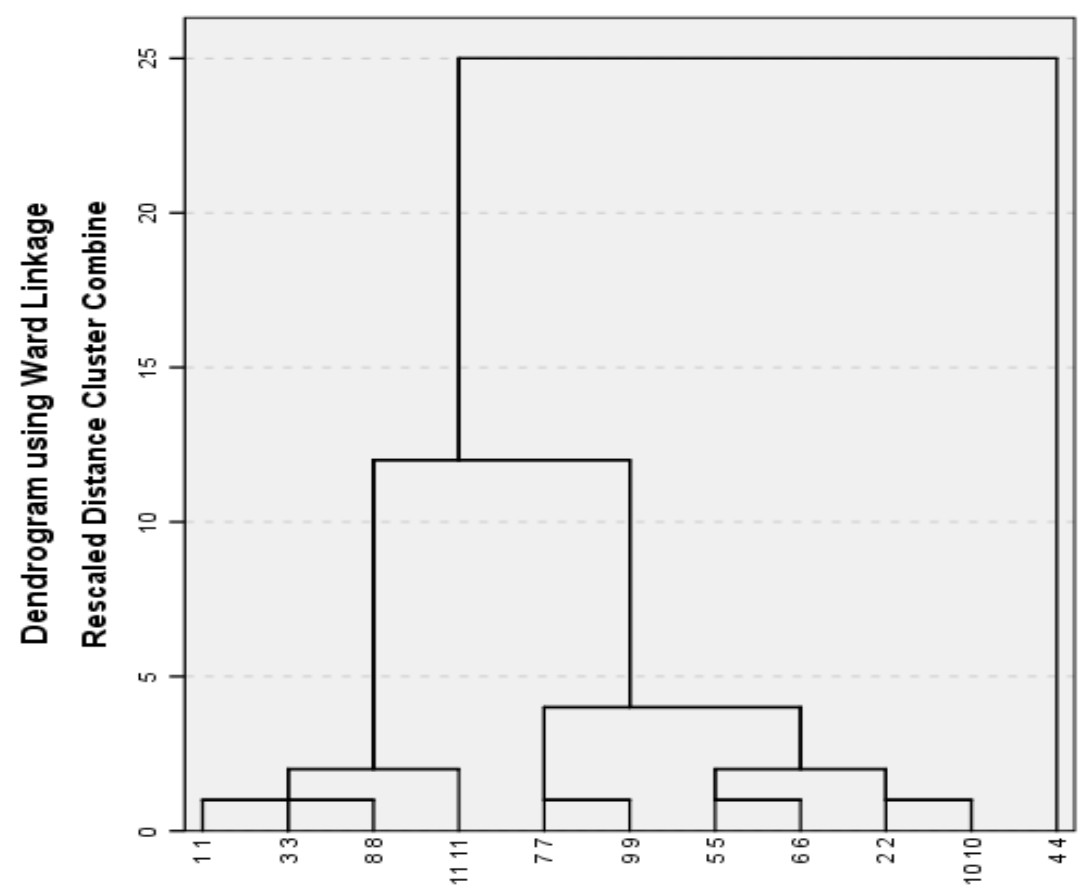

Note: 1; Population-1, 2; Population-2, 3; Population-3, 4; Population-4, 5; Population-5, 6; Population-6, 7; Population-7, 8; Population-8, 9; Population-9, 10; Bezostaja-1, 11; Kunduru-1149.

Nutrition- and health-wise wheat has advantages. Wheat samples here contained 10-16\% protein, which may provide $1 / 5$ of daily protein requirement when $100 \mathrm{gr}$ was consumed per day. If we look at the energy value provided by wheat, it provides $1 / 3$ of our daily energy. Furthermore, fat, ash, cellulose, and nutrients, bioactive molecules, and antioxidants do exist in wheat. Therefore, wheat also is a protective food against colon cancer, constipation, and cholesterol. Crude cellulose use of wheat is beneficial for healthy nutrition of pulp builder, bowel movement regulator and enhancer with a bowel cancer and anti-constipation effect. This is important in weight loss regimes as it is a popular issue these days.

Overall, different results were obtained for macro-micro elements between einkorn, emmer, durum, and bread wheat. Old hulled einkorn and emmer wheats used not to be preferred due to their low yield and difficult harvest. However, nowadays, old hulled wheats are so popular for their health advantages. $\mathrm{N}, \mathrm{P}_{2} \mathrm{O}_{5}, \mathrm{~K}_{2} \mathrm{O}, \mathrm{K}, \mathrm{Na}, \mathrm{Fe}, \mathrm{Ca}, \mathrm{Zn}, \mathrm{Mn}$, and $\mathrm{Mg}$ were highly significantly different ( $p>0.05$ ) except for $\mathrm{Cu}$ (Table 3). Copper richness in the samples may be due to copper mine prevalence in the Western Black Sea Region. More detailed further research, of course, will clarify the issue even better. In particular, the effects of heavy metals on the plants can be taken into consideration because of their toxicity. The tolerances of plants against heavy metals toxicity, the type and the amount of metal, its usefulness, the severity and the type of damage, and the process of damage formation may affect the development and viability of plants. Aluminium, vanadium, arsenic, mercury, lead, cadmium, and selenium are toxic against plants. Excessive accumulation of heavy metals in tissues and organs, whether or not an absolute essential element for plant growth, adversely affects the development of vegetative and generative organs of plants, animals, and humans. 
Figure 2. Dendogram of 11 soil samples based on $\mathrm{CaCO}_{3}$, active lime, $\mathrm{EC}, \mathrm{K}_{2} \mathrm{O}$, organic matter, $\mathrm{P}_{2} \mathrm{O}_{5}$, water saturation, saturation with water $\mathrm{pH}$, total salt, total $\mathrm{N}, \mathrm{Na}, \mathrm{K}, \mathrm{Fe}, \mathrm{Cu}, \mathrm{Ca}, \mathrm{Zn}, \mathrm{Mn}$, and $\mathrm{Mg}$.

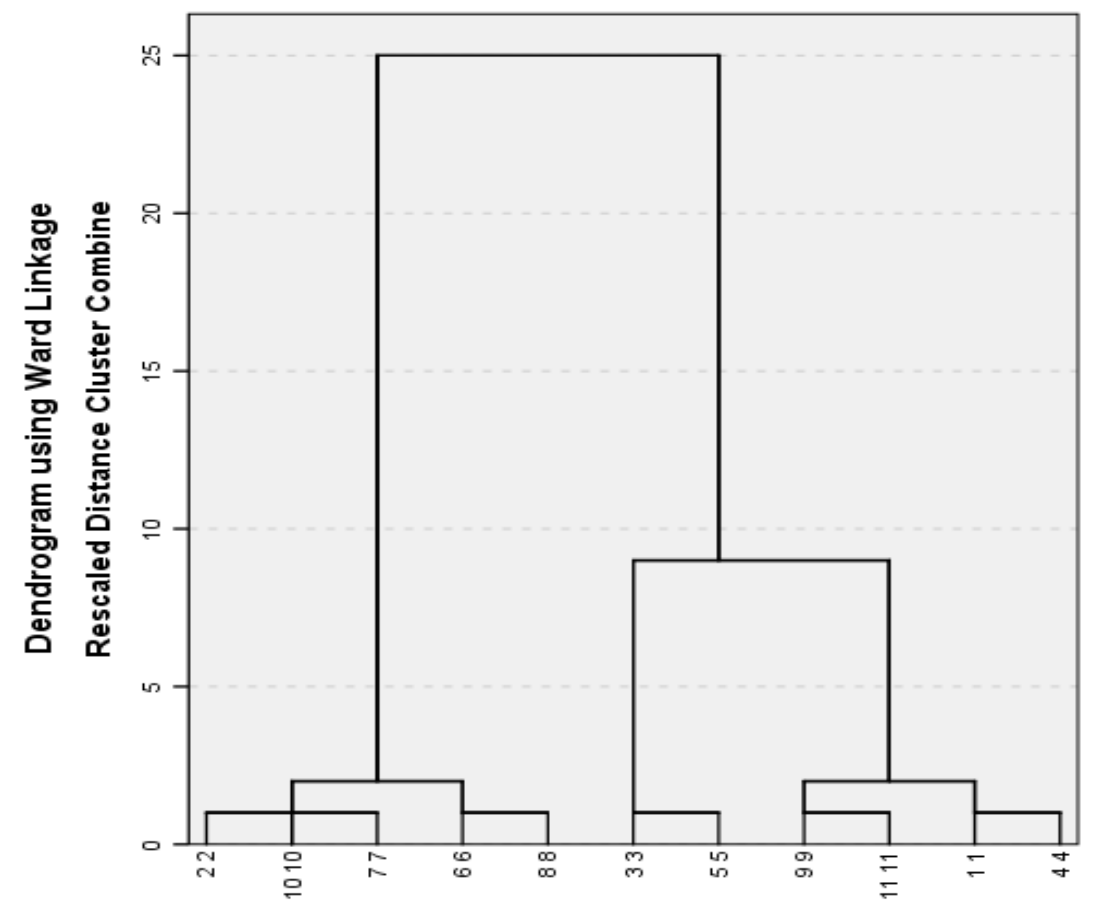

Note: 1; Population-1, 2; Population-2, 3; Population-3, 4; Population-4, 5; Population-5, 6; Population-6, 7; Population-7, 8; Population-8, 9; Population-9, 10; Bezostaja-1, 11; Kunduru-1149.

\section{CONCLUSION}

Culture landraces and ancient hulled wheat have recently become popular again because of their quality and health concerns raised by humans. Their broad gene pool induced by their heterozygous-heterogenous genetics structures makes their possible successful usage in plant improvement programs. Although their yields are lower and they cannot compete for yield and profitability with modern wheat varieties, their cultivation areas have been continually increasing these days due to the reasons. Many studies like this, therefore, have been carried out; many more still need to be conducted, though.

\section{Acknowledgments}

We thank Scientific Research Projects (BAP) Bolu Abant İzzet Baysal University for providing financial support (BAP Project number is BAP - 2016.03.01).

\section{Declaration of Conflicting Interests and Ethics}

The authors declare no conflict of interest. This research study complies with research and publishing ethics. The scientific and legal responsibility for manuscripts published in IJSM belongs to the authors.

\section{Authorship Contribution Statement}

Nusret Zencirci: Investigation, Resources, Visualization, Writing - original draft. Fatma Pehlivan Karakaş: Investigation, Formal Analysis, Writing - Review - Editing. Bülent Ordu: Statistical Analysis, Explanation.

\section{Orcid}

Nusret Zencirci (D) https://orcid.org/0000-0003-3460-7575

Fatma Pehlivan Karakaş (iD https://orcid.org/0000-0001-5245-6294

Bülent Ordu (iD https://orcid.org/0000-0001-5245-6294 


\section{REFERENCES}

Allison, L. E. (1965). Organic Carbon. In: Black C.A., Ed., Methods of Soil Analysis, ASACSSA-SSSA, Madison, 1367-1389.

Anonymous, (1993). Nordisk Metodik komité for Næringsmidler Nordic Committee on Food Analysis.

Anonymous, (1998). Nordisk Metodikkomité for Næringsmidler Nordic Committee on Food Analysis.

Anonymous, (2009). ISO 7971-3: 2009 (en): Cereals - Determination of bulk density, called mass per hectolitre - Part 3: Routine method.

Anonymous, (2010). AACC Approved Methods of Analysis. 11 $1^{\text {th }}$ Edition American Association of Cereal Chemist (AACC) St. Paul, MN USA ISBN 978-1-891127-68-2.

Anonymous, (2013). Ministry of Education Food Technology in Food Ham Fiber Type, Ankara.

Anonymous, (2016). Ministry of Education Laboratory Services Cereal Analysis, Ankara.

Arzani, A., \& Ashraf, M. (2017). Cultivated ancient wheats (Triticum spp.): A potential source of health-beneficial food products. Comparative Review of Food Science and Food Safety, $16,477-488$.

Ayyıldız, M. (1983). Sulama Suyu Kalitesi ve Tuzluluk Problemleri [Irrigation Water Quality and Salinity Problems] A.Ü Ziraat Fak Yayınları, Yayın No: 879 Ders kitabı, 344 Ankara.

Berger, K. C., \& Troug, E. (1939). Boron determination in soils and plants. Industrial Engineering Chemistry and Analytical Edition, 11, 540-545.

Black, C. A. (1965). Methods of Soil Analysis Part 2, Chemical and Microbiological Properties. American Society of Agronomy, Inc, Publisher, Madison, Wisconsin, USA.

Bower, C. A., Wilcox, L. V. (1965). Soluble Salts. CA Black Methods of Soil Analysis Part 2. American Society of Agronomy, Inc, Publisher, Madison, Wisconsin, USA.

Çağlar, K. Ö. (1949). Toprak Bilgisi [Soil]. A.Ü. Yayın No 10.

Carson, P. L. (1980). Recommended potassium test. In: Recommended chemical soil test procedures for the North Central Region. Revised Edition, North Central Regional Publication No.221. North Dakota Agricultural Experiment Station Publication, North Dakota State University, Fargo, USA.

Chapman, H. D., \& Pratt, P. F. (1961). Methods of analysis for soils, plants and waters. University of California, Los Angeles, 60-61, 150-179.

Cummins, A. G., \& Roberts-Thomson, I. C. (2009). Prevalence of celiac disease in the Asia Pacific Region. Gastroenterology Hepatitis, 24, 1347-1351.

Doll, E.C., Lucas, R.E., 1973. Testing soils for potassium, calcium and magnesium. In: Walsh, L.M., Beaton, J.D. (Eds.), Soil Testing and Plant Analysis, 3rd Edition. SSSA Book Ser. 3 SSSA Madison, WI.

Drouineau, G. (1942). Dosage rapide du calcaireactif des sols. Nouvelles donn6es sur la r6o6tition et la nature des fractions calcaires. Annals of Agronomy, 2, 441-450.

Dubcovsky, J., \& Dvorak, J. (2007). Genome plasticity a key factor in the success of polyploid wheat under domestication. Science, 316, 1862-1866.

Emmanuel-Ikpeme, C., Orim, P. H., \& Okirii A. 2014. Comparative evaluation of the nutritional, phytochemical and microbiological quality of three pepper varieties. Journal of Food and Nutrition Sciences, 2(3), 74-80.

Follet, R. H. \&Lindsay, W.L. (1970). Profile distribution of zinc, iron, manganese and copper in Coloradosoil. Colorado Experiment State Bulletin, 110, 79.

Giuliani, A., Karagöz, A., \& Zencirci, N. (2009). Emmer (Triticum dicoccon) production and market potential in marginal mountainous areas of Turkey. Mountain Research Development, 29, 220-229. 
Hanway, J. J. (1968). Standart Laboratory Methods for Soil, Plant, Fertilizer. International Atomic Energy Agency Vienna.

Heun, M., Sch€afer-Pregl, R., Klawan, D., Castagna, R., Accerbi, M., Borghi, B., \& Salamini, F. (1997). Site of einkorn wheat domestication identified by DNA fingerprinting. Science, 278, 1312-1314.

Hindistan, M., \& İnceoğlu, İ. (1962). Toprakta pH Tayini [Ph Determination in Soil]. Ministry of Agriculture, Soil-Water Institure, Publication, No: 10.

Horwitz, W. (1955). Official Methods of Analysis of the Association of Official Agricultural Chemists. Washington DC, USA.

Jackson, M. L. (1958). Soil Chemical Analysis. Prentice-Hall, Inc Englewood Cliffs N.J.

Kan, M., Küçükçongar, M., Keser, M., Morgounov, A., Muminjanov, H., Özdemir, F., \& Qualset, C. (2015). Wheat Landraces in Farmers' Fields in Turkey National Survey, Collection and Conservation. Food and Agriculture Organization of the United Nations Ankara 1-157.

Karagöz, A. (1996). Agronomic Practices and Socioeconomic Aspects of Emmer and Einkorn Cultivation in Turkey. In: Padulosi S, Hammer K, Heller J, editors. Hulled Wheat. Promoting the Conservation and Use of Underutilized and Neglected Crops. Proceedings of the First International Workshop on Hulled Wheats. Rome Italy: IPGRI (International Plant Genetic Resources Institute) pp. 172-177.

Lachman, J., Miholova, D., Pivec, V., Jiru, K., \& Janovska, D. (2011). Content of phenolic antioxidants and selenium in grain of einkorn (Triticum monococcum), emmer (Triticum dicoccum) and spring wheat (Triticum aestivum) varieties. Plant Soil Environment, 57, 235243.

Mclean, E. O. (1973). Testing Soils for pH and Lime Requirement. Walsh, L.M., J.D., Beaton (Ed.) Soil Testing and Plant Analysis. Soil Sci Soc Amer Inc, Madicon Wisconsin, USA.

Nesbitt, M. (1995). Plants and People in Ancient Anatolia. Bibliographical Archives, 58, 6881.

Nesbitt, M., \& Samuel, D. (1996). From Staple Crop to Extinction? The Archaeology and History of the Hulled Wheats. In: Padulosi S, Hammer K, Heller J (Eds) Hulled wheats. Proceedings of the First International Workshop on Hulled Wheats, 21-22 July 1995, Castelvecchio Pascoli Italy. IPGRI Rome pp 41-100.

Olsen, S. R., Cole, C. V., Watanabe, F. S., \& Dean, L. A. (1954). Estimation of available phosphorus in soils by extraction with sodium bicarbonate. Circular, Vol 939 (p. 19). US Department of Agriculture.

Özbek, N., \& Aydeniz, A. (1967). Toprak Verimliliği Alanındaki Laboratuvar Çalışmalarında Kullanilan Alet ve Malzemeye ait Laboratuvar El Kitabı [Handbook on Equipment and Devices Utilized in Soil Fertility Laboratuary]. Ankara University Agricultural Faculty Publications, No: 301.

Özkan, H., Willcox, G., Graner, A., Salamini, F., \& Kilian, B. (2010). Geographic distribution and domestication of wild emmer wheat (Triticum dicoccoides). Genetic Resources and Crop Evolution, 58, 11-53.

Öztan, B., \& Munsuz, G. (1961). Saturasyon Macunu ve Yüzde Saturasyon [Saturation Paste Percent Saturation]. Toprak Gübre Araştırma Enstitüsü, Technical Publications No: 6, Ankara.

Öztan, B., \& Ülgen, H. (1961). Saturasyon Macununda ve Ekstraktında Tuz Tayinleri [Salt Determination in Saturation Paste and Extact]. Toprak Gübre Araştırma Enstitüsü, Technical Publications No:7, Ankara.

Peech, M. (1965). Hydrogen-Ion Activity. CA Black (Ed.) Methods of Soil Analysis Part 2. Amer Soc Agr Inc, Madison Wisconsin, USA. 
Pekcan, G., \& Köksal, E. (2006). Vitamin ve mineral alım düzeylerinin değerlendirilmesinde diyet referans değerleri [Diet Referans Values in Evaluation of Vitamin and Mineral Intake]. Türkiye Klinikleri [Turkey Clinics]. Pediatry Science, 2, 8-1.

Peng, J. H., Sun, D., \& Nevo, E. (2011a). Will emmer wheat, Triticum dicoccoides, occupies a pivotal position in wheat domestication process. Australian Journal of Crop Science, 5(9), 1127-1143.

Peng, J. H., Sun, D., \& Nevo, E. (2011b). Domestication, evaluation, genetics and genomics in wheat. Molecular Breeding, 28, 281-301.

Pomeranz, Y. (1971). Wheat Chemistry and Technology. AA Cereal Chem, St. Paul Minnesota, USA 10742.

Pratt, P. F. (1965). Potassium. CA Black. Methods of Soil Analysis. American Society of Agricultue Inc, Publisher Madison, Wisconsin, USA.

Richards, L. A. (1954). Diagnosis and Improvement of Saline and Alkali Soils. USDA Agriculture Handbook No: 60.

Rossi, A. M., Villarreal, M., Juárez, M.D., \& Sammán, N. C. (2004). Nitrogen contents in food: a comparison between the Kjeldahl and Hach methods. Anales de la Asociación Química Argentina, 92, 99-108.

Shewry, P. R. (2009). Wheat. Experimental Botany, 60, 1537-1553.

Suchowilska, E., Wiwart, M., Kandler, W., \& Krska R. (2012). A Comparison of macro- and microelement concentrations in the whole grain of four Triticum species. Plant Soil Environment, 58, 141-147.

Szabo, A. T., \& Hammer, K. (1996). Notes on the taxonomy of Farro: Triticum monococcum, T. dicoccon, and T. spelta. In: Padulosi S, Hammer K, Heller J (Eds) Hulled wheats. Proceedings of the first international workshop on hulled wheats 21-22 July 1995 Castelvecchio Pascoli Italy IPGRI Rome pp 2-40.

Ülgen, N., \& Ateşalp, M. (1972). Toprakta Total Azot Tayini [Nitrogen Determination in Soil]. Toprak ve Gübre Araştırma Enstitüsü Teknik Yayınlar Serisi: 22 Ankara.

Viets, F. G. (1962). Chemistry and availability of micronutrients. Agricultural Food Chemistry, $10,174$.

Walkley, A. (1946). A critical examination of a rapid method for determining organic carbon in soils. Soil Science, 63, 251-263.

Zohary, D., \& Hopf, M. (2000). Domestication of Plants in the Old World. $3^{\text {rd }}$ edn 316 pp Oxford University Press. 